\title{
Quantifying subsidence and isostatic readjustment using sedimentary paleomarkers, example from the Gulf of Lion
}

\author{
Rabineau Marina ${ }^{1,{ }^{*}}$, Leroux Estelle ${ }^{1,2}$, Aslanian Daniel ${ }^{2}$, Bache F. ${ }^{3}$, Gorini Christian ${ }^{4}$, Moulin \\ Maryline $^{2}$, Molliex Stephane ${ }^{1,2}$, Droz Laurence ${ }^{1}$, Dos Reis Antonio ${ }^{5}$, Rubino J. L. ${ }^{6}$, Guillocheau \\ Francois $^{7}$, Olivet Jean-Louis ${ }^{2}$
}

${ }_{1}^{1}$ UBO, CNRS, IUEM, UMR 6538,Domaines Ocean, F-29280 Plouzane, France.

${ }^{2}$ IFREMER, Ctr Brest, GM, F-29280 Plouzane, France.

${ }^{3}$ GNS Sci, Lower Hutt 5040, New Zealand.

${ }^{4}$ Univ Paris 06, ISTEP, UMR 7193, F-75005 Paris, France.

${ }^{5}$ UERJ Brazil, Dept Oceanog Geol, BR-20550900 Rio De Janeiro, RJ, Brazil.

${ }^{6}$ CSTJF, TOTAL, TG, ISS, F-64018 Pau, France.

${ }^{7}$ Univ Rennes 1, Geosci Rennes, UMR 6118, F-35042 Rennes, France.

* Corresponding author: Marina Rabineau, tel.: +33 0298498728 ; fax: +33 0298498760 ; email address : marina.rabineau@univ-brest.fr

\begin{abstract}
:
Passive margins are characterised by an important tectonic and thermal subsidence, which favours a good preservation of sedimentary sequences. This sedimentation in turn enhances the subsidence because of loading effects. We present here a direct method based on sedimentary markers seen on seismic data, to evaluate total subsidence rates from the coast to the outer shelf and to the deep basin in the Gulf of Lion, from the beginning of massive salt deposition up to present day (the last circa $6 \mathrm{Ma}$ ) with minimal theoretical assumptions. On the shelf, the Pliocene-Quaternary subsidence shows a seaward tilt reaching a rate of $240 \mathrm{~m} / \mathrm{Ma}( \pm 15 \mathrm{~m} / \mathrm{Ma})$ at the shelf break $(70 \mathrm{~km}$ from the present day coastline) (i.e. a total angle of rotation of $0.88^{\circ}\left(0.16^{\circ} / \mathrm{Ma}\right)$ ). We were also able to measure and quantify for the first time the isostatic rebound of the outer shelf due to the Messinian salinity crisis (MSC). This value is very high and reaches up to $1.3 \mathrm{~km}$ of uplift during the crisis around the Herault-Sète canyon heads (around $1.8 \mathrm{~km} / \mathrm{Ma}$ ). On the slope, we also find a seaward tilting subsidence from $\mathrm{Km} 90$ to $\mathrm{Km}$ 180 with a measured angle of $1.41^{\circ}$. From $180 \mathrm{~km}$ to the deepest part of the basin, the total subsidence is then almost vertical and reaches $960 \mathrm{~m} / \mathrm{Ma}( \pm 40 \mathrm{~m} / \mathrm{Ma})$ during the last $5.7 \mathrm{Ma}( \pm 0.25 \mathrm{Ma})$ in the deepest part of the basin. The subsidence is organised in three compartments that seem related to the very deep structure of the margin during the opening of the Liguro-provencal basin. These very high total subsidence rates enable high sedimentation rates along the margin with sediments provided by the Rhône river flowing from the Alps, which in turn enable the detailed record of climate evolution during Pliocene-Quaternary that make of the Gulf of Lion a unique archive.
\end{abstract}




\section{Highlights}

- Quantifying subsidence using sedimentary markers and minimal assumptions. D Quantifying isostatic rebound related to the MSC using sedimentary markers. Subsidence is organised in three compartments separated by hinge points.

Keywords : subsidence, pliocene-quaternary, messinian salinity crisis, isostasy, Mediterranean Sea, Gulf of Lion 


\section{Introduction}

The detection and measurement of land subsidence can be done over recent time with specialized instrumentation designed to precisely measure and monitor surface deformation over limited areas. Measured rates can be of the order of $40 \mathrm{~mm} /$ year (i.e. $40 \mathrm{~m} / \mathrm{ka}$ ) (Amelung et al., 1999). Over geological time-scale (million of years), subsidence rates are generally much lower and can not be measured with instruments. Quantification of subsidence is therefore not straightforward, it has to be defined using the final geological record preserved in basins. Defining and quantifying the relative role of parameters (subsidence, eustasy, sediment supply) interfering to produce the final sedimentary architecture of basins has been one of the main task of Seismic and Sequence Stratigraphy, as developed in the early 80's (Mitchum and Vail, 1977; Posamentier et al., 1988). Synchronously, developments of quantitative techniques in analysis of sedimentary basins (geohistory analysis) were developed (Allen and Allen, 1990; Jervey, 1988; Robin et al., 1996; Van Hinte, 1978). Their aim is to produce a curve for the subsidence and sediment accumulation rates through time. The final product is reached after a number of corrections (decompaction, paleobathymetry and absolute sea-level fluctuations) based on available dataset. This backstripping depends on the isostatic response of the lithosphere. The total subsidence is then usually partitioned into that caused by tectonic driving force and that due to sediment load inducing flexure (Allen and Allen, 2005). Practically some theoretical or empirical laws and assumptions are needed (e.g. Airy vs regional flexure). Backstripped tectonic subsidence curves are then used to investigate basin-forming mechanisms (e.g. stretching with $ß$ factor, flexure, ...) and their anomalies.

This paper aims to use a different method to quantify total subsidence rates with a direct use of sedimentary geometries. Total subsidence rate is defined as the vertical movement of sedimentary paleomarkers whatever the factors responsible for it.

\section{Previous Work of Subsidence studies in the Gulf of Lion}

Subsidence in the Gulf of Lion margin (Fig. 1) has long been considered as a classical Atlantictype passive margin with a general and regular seaward tilt of the shelf (Le Pichon et al., 1971; Watts \& Ryan, 1976; Ryan, 1976; Montadert et al., 1978; Steckler \& Watts, 1980; Burrus, 1989). While uniform extension models (McKenzie, 1978) were largely used to explain the evolution of such margins, many discrepancies with the predictions of these models have been highlighted in the Gulf of Lion. (Rehault et al., 1984; Bessis, 1986; Burrus et al., 1987) concluded that present-day depth of the basin is at least $1000 \mathrm{~m}$ deeper than what it should be (if the model was right and applied here). Kooi et al. (1992) tested several depths of necking and a model of local isostasy in the Gulf of Lion and showed that local isostasy could not account for the present-day configuration of the basin. In 1999, Séranne confirmed that the Gulf of Lion margin displays structural and stratigraphic features similar to 'Atlantic-type' margins, however he suggested that the Oligocene rifting of the Gulf of Lion represents the initial stage of a succession of rifting events and back-arc basin formation (Séranne, 1999), due to continuously retreating subduction during convergence of Africa and Europe (Rehault et al., 1984; Jolivet et al., 2006). A colder mantle may therefore account for the abnormal subsidence of the basin (500 $\mathrm{m} / \mathrm{Ma}$ ), and could be a result of the over 40 Ma long subduction beneath this area (Serrane, 1999; Chamot-rooke et al., 1999). While the subsidence evolution in two phases seems to be accepted by most of the authors, the timing and the quantification differ. In 1980, Steckler and 
Watts (1980) used biostratigraphic data from commercial wells and described a relatively small volume of syn-rift sediments compared to post-rift sediments. This first type of discrepancy was not corroborated by more recent studies, which described a great thickness of synrift sediments (Bessis, 1986; Guennoc et al., 2000). This observation led Bessis and Burrus to introduce the concept of "paradox of stretching" in the Gulf of Lion (i.e. the high values of stretching required are not consistent with the crustal thinning ratio deduced from seismic refraction data). Other studies in the area have shown that tectonic subsidence associated with rifting was small and local and that most of the subsidence only started in Miocene time, confirming the previous observation of Steckler and Watts (1980), as a consequence of post-rift thermal cooling enhanced by sediment loading (De Voogd et al., 1991; Gorini et al., 1994).

All these earlier observation showed that the earlier classical 'Atlantic-type' model did not fully apply here nor the "flexural sediment loading models" (Kooi et al., 1992). The recent study of Bache et al. (2010) finally showed that most of the Gulf of Lion margin is subaerially exposed during an early phase of rifting despite significant thinning. This observation has also been described on several margins leading to a deep revision of principles of passive margin formation (Moulin et al., 2005; Dupré et al., 2007; Péron-Pivindic and Manatschal, 2009; Aslanian et al., 2009; Labails et al., 2009).

\subsection{Estimated Pliocene-Quaternary subsidence rate}

Réhault et al., (1984), Bessis (1986), Burrus (1989), and (Burrus and Audebert, 1990) noted an enhanced total subsidence rate during the Pliocene-Quaternary (5.33 Ma) in the very deep basin of the Gulf of Lion that remains largely unexplained and could be related to Alpine compression (Burrus \& Audebert, 1990) or compressional late stage reactivation of the Gulf of Lion and other western Mediterranean back arc systems (Cloetingh \& Kooi, 1992; Kooi \& Cloetingh, 1992). This increase is also observed in most North Atlantic region and may reflect a period of increased levels of neotectonic activity interplaying with periodes of (de)glaciation (Cloetingh \& Kooi, 1992). Guennoc et al. (2000) produced a reconstructed paleo-Messinian surface by correcting the present day Messinian surface from water and Pliocene-Quaternary sediment loading. This correction showed subsidence of at least 188-225 (from the middle to the outer shelf) to $363 \mathrm{~m} / \mathrm{Ma}$ on the slope (GLP2). However, thermal cooling and isostatic readjustment were not taken into account.

\subsection{Estimated Late Quaternary subsidence}

(Rabineau et al., 2006, Rabineau et al., 2007) calculated subsidence rate of the western shelf of the Gulf of Lion for the last 500, 000 years. In this area, erosional surfaces are the result of erosion during sea-level lowering related to glacial/interglacial 100,000 yr cycles (Aloïsi, 1986), (Berné et al., 2004), (Rabineau et al., 2005). These surfaces are very well preserved as they have been "frozen" by the rapid sea-level rise of the asymmetric sea-level cycles. The end of each regressive erosional surface can therefore be dated as the age of successive glacial maxima. Rabineau et al. (2006) measured the tilt on the seismic profiles by the inclination of successive dated erosional surfaces (MIS2, 6, 8, 10 and 12), and obtained $250 \mathrm{~m} / \mathrm{Ma}$ of subsidence at $70 \mathrm{~km}$ from the coast around the Aude and Hérault canyon heads, the rotation point being $13.5 \mathrm{~km}$ offshore of present day coastline.

Despite their discrepencies, all earlier studies showed that subsidence rates are particularly high in the Gulf of Lion whatever the factors responsible for it. 


\section{Material and Methods}

In this study we used the database built during the French GDR Marges and Actions Marges Program thanks to the collaboration of TOTAL which gave access to all their conventional seismic lines, high resolution multi-channel data (LRM lines in particular) and industrial boreholes (Fig. 1). Additional high and very high resolution seismic profiles from IFREMER were also used (Fig. 1). In order to have as many chronostratigraphic constraints as possible within the sedimentary column, we used seismic profiles of different resolution but at the same position, so that the well-constrained and well-dated Quaternary surfaces can also be placed on lower resolution profiles (see Supplementary data Fig. S1). Seismic Stratigraphy principles were applied to interpret seismic profiles (Payton, 1977) (Fig. 3 and 4). Key reflectors identified and correlated at regional scale with key sedimentological reference points (shoreline, offlap break, toeset break), they are labelled MES (Margin Erosional surface in pink), plio11 (green), q10 (red), D30 (orange).

\subsection{D and 2D study from seismic stratigraphy and sequence stratigraphy}

Most authors recognise three factors variable in time, that control directly the creation, expression and organisation of sedimentary sequences (Vail et al., 1987; Jervey, 1988; Posamentier, 1988a, Posamentier, 1988b, Guillocheau, 1991...) : (1) Eustatism (with absolute sea-level variations), (2) Movements of the substratum (subsidence s. I. and compaction) and (3) Sedimentary Fluxes (Fig. 2A).

Conceptual models are based on the fact that sedimentary strata can be described as a logical succession of units, which geometry and localisation on a coast-to-basin depositional profile is a function of varying Relative Sea-Level (RSL) (also named « Accommodation»). Accommodation is the space comprised at a given time between the substratum (or a reference level) and the sea-level, that is, the space created either by subsidence or by eustatism and is independent of the presence or not of sediments (Fig. 2). This accommodation can then be filled, completely or partially, by sediments, which will form depositional sequences. Note that many other parameters have an impact on the detailed nature of the sediments and deposition style, but they have no impact on accommodation. Calculation of accommodation at a given point and a given time can be handled in two ways: (1) by additioning the value of subsidence and of sea-level (Fig. 2A), (2) by additioning the thickness of sediments and their bathymetry at time of deposition (Fig. 2B). Variation of Accommodation can be calculated between two time periods, following equation shown in Fig. 2 (Robin et al., 1996). Fig. 2C shows an example with a tilting margin.

\subsection{Time-depth conversion}

Seismic profiles and their interpretation were converted from TWTT to depth, in order to measure directly tilting or movements of the substratum (Fig. 2C). On the shelf we used velocities measured in two wells: Rascasse and Tramontane (Figs. 1 and 5A and 5B). Tramontane well is located $30 \mathrm{~km}$ from the coast, $6 \mathrm{~km}$ to the SW of LRM18 profile. Rascasse well is located in a more distal part of the profile on the outer shelf at $55 \mathrm{~km}$ from the coast (Figs. 1 and 5). Measured boreholes velocities were correlated to seismic profiles and showed that we could distinguish specific velocities for different sedimentary packages. We therefore identified the topset, the foreset, and the bottomset of each sigmoidal prism with specific velocities related to the average sand/silt/shales ratios in each area. We therefore defined a 2D 
velocity profile (Fig. 5C) on the shelf used to convert interpreted reflectors from TWTT to depth (m).

On the slope and deep sea we used ESP (Expanding Spread Profiles) shot along the ECORS profile (De Voogd et al., 1991), and interpreted by (Pascal et al., 1993), together with velocities obtained by tomographic inversion from new refraction data acquired during the Sardinia Cruise (Aslanian et al., 2012; Gailler, 2009) to build the 2D velocity model (Fig. 5D). Velocities measurements in GLP2 well (1246 m water depth, Figs. 1, 4 and 5) showed velocities from $1800 \mathrm{~m} / \mathrm{s}$ at the top of the well, $3400 \mathrm{~m} / \mathrm{s}$ at the base of Pliocene-Quaternary series, $3700 \mathrm{~m} / \mathrm{s}$ at base of salt thin layer, $4200 \mathrm{~m} / \mathrm{s}$ at base of Dm and $4900 \mathrm{~m} / \mathrm{s}$ in Miocene strata (Leroux, 2012). After time-depth conversion, we therefore obtain a 2D section of interpreted reflectors in depth (m) (Fig. 6).

\subsection{Dating of surfaces}

Very high-resolution profiles interpreted in earlier studies (Rabineau, 2001; Rabineau et al., 2005) showed that the last 5 erosional surfaces correspond to the last five glacial maximum erosions of 100,000 years cycles, with preservation of the shoreline on the outer shelf. The fifth surface D30 was interpreted as MIS12.2 (Rabineau et al. 2005, 2006) and therefore dated at 434, 000 years, according to orbitally tuned isotopic Specmap curve (Imbrie, 1984). These datings have been fully ground-truthed by Promess drillsites (Bassetti et al., 2008; Sierro et al., 2009).

The end of the Messinian erosional surface (MES) is dated at $5.33 \mathrm{Ma}$ according to the GSSP (Global Stratotype Section and Point) of the Lower Pliocene Zanclean Stage dated astronomically by (Van Couvering et al., 2000 ). Most authors therefore agreed to date the end of the Salinity crisis at $5.33 \mathrm{Ma}$ (CIESM, 2008). Concerning the timing for the initiation of the deep-basin Lower Unit (LU), the massive salt (MU), the base of Upper Evaporites (UU) controversies are still numerous and several ages are suggested. At present day, no definitive proof is available, as no drilling has sampled these layers. In this paper we will therefore take the two extremes for ages estimation and will consider them as our uncertainty. Therefore we consider that the base of massive salt deposition is dated between $5.96 \mathrm{Ma}$ (the same age as lower evaporites in peripheric basins) (Krijgsman et al., 1999 for example) and somewhere between 5.6 and 5.46 Ma (after the major draw down and before the rapid flooding) (CIESM, 2008; Bache et al., 2012). Therefore we consider the age for the base of salt as dated between 5.96 and $5.46 \mathrm{Ma}$, i.e $5.7 \mathrm{Ma}( \pm 0.25 \mathrm{Ma})$.

\section{Results}

\subsection{Sedimentary paleo-markers}

The erosional surface D30 was plotted on LRM18 shelf profile (Fig. 3). Below D30, other erosional surfaces could be plotted: surface q10 corresponds to a major erosional surface that lies around $450 \mathrm{~ms}$ (or $400 \mathrm{~m}$ after time-depth conversion) below present day sea-level and seals an important incision on the outer shelf around shotpoint 3100-3300. At the base of the profile a proeminent erosional surface appears which corresponds to the well-known Messinian margin erosional surface (MES) dated at $5.33 \mathrm{Ma}$. Between the MES and the upper two surfaces (D30 and q10), we distinguished a number of large clinoforms (around $500 \mathrm{~m}$ high). 
Clinoforms are named $\mathrm{p} 1$ to $\mathrm{p} 14$, and all show a gently dipping linear topset part, a highly dipping foreset part curving more or less progressively to a gently dipping bottomset part (Fig. 6). Topset parts of clinoforms are preserved through time, and show an increased topset-slope with increasing age. The overall organisation can be described as a prograding-agrading margin with sigmoïdal clinoforms (Mitchum et al., 1977a). Clinoform p11 (green) on the shelf shows an important erosion that truncates the topset part of earlier clinoforms p10 and p9. In the upper part of the section some erosional V-shaped filled incisions are related to paleocanyons heads that have been filled (Rabineau et al., 1998). The organisation and functioning of Quaternary canyons have been described in details in the area (Baztan et al., 2005; Gaudin et al., 2006; Lastras et al., 2007; Canals et al., 2009; Amblas et al., 2012...). The oldest observed incision of that type has been observed just above p11 clinoform (Rabineau, 2001) as also observed by (Lofi et al., 2003), but with a different age.

The Messinian Margin Erosional surface (MES) can be followed from the shelf to the slope. Around $62 \mathrm{~km}$ from the coast the surface divides into two surfaces (Fig. 4) with a basal erosional surface truncating Miocene deposits identified as BES using the terminology defined in (Lofi et al., 2011). This BES correlates seaward to a conformable surface called BS in the deepest basin. Above this surface, two units are indentified in the deep basin LU0 and LU1 as described and interpreted as Messinian turbidites and evaporites by Bache et al., 2009 and 2012. Above LU, a thick layer of transparent seismic facies associated to an homogeneous salt layer (halite) also called the MU (Mobile Unit) in (Lofi et al. 2011) is overlain by a layer of "Upper Evaporites"(UU) that has been drilled by DSDP and ODP drilling in the Mediterranean Sea (Hsü et al., 1973). MU and UU deposits pinch-out landward towards another flat erosional surface identified by Bache et al. 2009, 2012 as a ravinement surface (RS) related to the slow increase of Mediterranean sea-level prior to the very drastic increase of sea-level suddenly drowning the Mediterranean Sea.

\subsubsection{Significance of offlap breaks or topset-foreset breaks}

The offlap-break (or clinoform breakpoint) is described in sequence stratigraphy as the inflexion point between topset and foreset (Vail et al., 1991). It has very often been considered as the position of the shoreline, i.e. the "Zero» of sea-level. Topsets sediments were therefore attributed to continental facies (deltaic or alluvial plain). Foresets in that case represent the delta front or shoreface shallow environment. Numerous discussions recently occurred about this notion, and pointed to the abuses of this interpretation (Cattaneo et al., 2003; Cattaneo et al., 2007; Emery et al., 1996; Helland-Hansen and Hampson, 2009; Henriksen et al., 2009). Those recent publications clearly showed that clinoforms and offlap break can both occur at very different scales (from current ripples, to shoreline break and shelf-edge break). Most recent IODP expedition 313, drilled Miocene rollover features on the New Jersey shelf and showed that they correspond to shoreface to nearshore environments (Miller et al., 2013).

Present day situation in the Gulf of Lion shows two kinds of offlap-breaks of very different scale (Fig. 3): the offlap break related to the shoreline and the offlap-break related to the shelf break. To avoid confusions we used a specific terminology with a shoreline-offlap break and a shelfofflap break (Figs. 3 and 6). At present day those two points lie respectively at water-depths of 0-10 m and 150-160 m. Earlier studies also demonstrated that the Last Glacial Maximum (LGM) paleo-shoreline, $20 \mathrm{ka}$ ago, is recorded on the outer shelf, at the top of $30 \mathrm{~m}$-thick sand bodies and at a present day bathymetry of $115 \mathrm{~m}$ (Aloïsi, 1986; Rabineau et al., 1998, 2005, 2006, Bassetti et al., 2006, 2008). This point is different from the shelf-offlap-break (at $150 \mathrm{~m}$ ) as shown on Fig. 3. Offlap breaks identified on seismic during Pliocene-Quaternary do not represent the shoreline but the shelf break and the height of clinoforms represents the slope. 
We assume that this paleobathymetry is the same for all identified shelf-offlap-breaks and can be estimated to be around $150 \mathrm{~m}$ (at high sea-level). Topsets of clinoforms represent subaerial to continental shelf environments. We also identified a toeset-offlap break at the base of foresets that we will use to calculate accommodation.

\subsubsection{Significance of base of salt surface}

Because the salt is a chemical sediment and has a ductile nature, which prevents a deposition as drapes on a slope, it is always deposited as flat horizontal layers. Present day slope of surfaces where salt layers were previously deposited therefore measures directly the amount of post-depositional subsidence.

\subsection{Measurements of subsidence rates}

\subsubsection{Calculation of Pliocene-Quaternary Subsidence rates on the shelf}

Two methods were used to calculate total Pliocene-Quaternary subsidence.

\section{A-Accommodation evolution at points (A and B) (Fig. 6).}

At the beginning of Zanclean, at point $A$, accommodation corresponds to the bathymetry of the first sediments deposited on the MES surface, i.e. the bottomsets of p2. In the absence of drillings, we can estimate this paleobathymetry by the addition of 1) the height of $\mathrm{p} 2$ foreset and 2) the bathymetry of the offlap break at that time, so Zanclean accommodation at point $A$ is 800 $\mathrm{m}$. At point $B$ it is more difficult to estimate accommodation because we are lacking appropriate marker to estimate paleowater depth of initial deposits. However, we can postulate that it is at least of the same order of magnitude $(800 \mathrm{~m}$, probably more). Note that this estimate is a regional estimate as the Messinian erosion surface is very irregular and can induce large thickness variations.

Present Day accommodation is easily calculated by adding the thickness of sediments and present-day bathymetry. At point $A$ this value is $1050 \mathrm{~m}$ and at point $B$ it is $2240 \mathrm{~m}$. So, the creation of accommodation between Pliocene and Present day is: $250 \mathrm{~m}$ at point $\mathrm{A}$ and $1440 \mathrm{~m}$ (as a maximum) at point $B$.

These amounts correspond to the sum of subsidence and eustatism variations. According to global estimates of eustatic variations, sea-level shows a regressive trend between Zanclean and present-day corresponding to a sea-level drop of -40 m (Blackwelder, 1981; Shackleton and Opdyke, 1977). For Miller et al., 2005 sea-level at $5.33 \mathrm{Ma}$ is $+48.8 \mathrm{~m}$ above present day sealevel. Other estimates give $+25 \mathrm{~m}$ (Kennett and Hoddell, 1993) or $+88 \mathrm{~m}$ (Haq, 1987). We averaged these values to $+50 \mathrm{~m}( \pm 25 \mathrm{~m})$ in our estimate.

We obtain $\Delta$ Subsi $=300 \mathrm{~m}$ at point $\mathrm{A}$ and a maximum of $1490 \mathrm{~m}$ at point $\mathrm{B}$.

If we date initial prism p1 at $5.33 \mathrm{Ma}$ (the earliest Zanclean deposits after the complete reflooding) we obtain subsidence rates of $56 \mathrm{~m} / \mathrm{Ma}$ at point $A$ and a maximum of $280 \mathrm{~m} / \mathrm{Ma}$ at point $\mathrm{B}$, at $70 \mathrm{~km}$ from the coast (Fig. 6). 
B- Tilt of erosion surfaces.

Using the same LRM18 depth-profile we analysed the tilt of erosional surfaces. In the upper part of the profile Quaternary erosional surfaces are related to glacial regression (Rabineau et al, 2005) slightly reworked during transgression (Bassetti et al., 2006). This surface can easily be approximated to a line with a slope of $1,5 \mathrm{~m} / \mathrm{km}\left(0,15 \%, 0,0859^{\circ}\right)$. This approximation of erosional surfaces in topset areas was done for all plotted clinoforms in the outer part of the profile (from p11 to present) (see Supplementary data Fig. S2 and Fig. 7). The lines show an increasing slope with increasing age of clinoforms. Topset of clinoforms (Figs. 2A and 7) can reach $15 \mathrm{~m} / \mathrm{km}\left(1.5 \%, 0.86^{\circ}\right)$ foresets can reach $50-62 \mathrm{~m} / \mathrm{km}\left(5.2-6.2 \%\right.$ or $\left.2.86-3.5^{\circ}\right)$ and bottomsets $3 \mathrm{~m} / \mathrm{km}$. All lines showed a common rotation point (RP) located $13 \mathrm{~km}$ landward of present-day coast. Observed increasing slopes are due to post-depositional tilting of the margin related to subsidence. However detailed analysis of slope adjustment showed that the straight line geometry did not completely fit in the landward part of clinoforms (Fig. S2). Further investigation on seismic profiles showed a small, but systematic deformation of reflectors around $32 \mathrm{~km}$ from the coast (Fig. 6 and S2). All reflectors from early Pliocene to p14 show the same deformation, whereas reflector q10 is much less deformed and D30 not deformed. We therefore conclude that there is a tectonic deformation with $50 \mathrm{~m}$ uplift in the landward part of the section. This deformation can be followed on several lines and mapped in the western area (see discussion and Fig. 8). It occurred around q10 reflector.

If we restore the landward part of the section before this deformation we find a good adjustment of topsets that can be propagated down to p1 clinoform with the same rotation point (Fig. 7).

Present-day bestfit straight line adjustment of the sea-floor lies at $150 \mathrm{~m}$ at $\mathrm{Km} 70$. The tilt between bestfit straight line of $\mathrm{p} 1$ and the bestfit straight-line of present day sea-floor brings line-p1 at $1430 \mathrm{~m}$ at $\mathrm{Km} 70$ (Fig. 7), i.e. $1280 \mathrm{~m}$ of subsidence. The angle of tilt is therefore $\alpha=0.88^{\circ}(=1.54 \%$ ) (see Fig. 2). As the first visible prism p1 on the shelf (appearing at Km6) lies directly on the Messinian surface, we can date this first prism as $5.33 \mathrm{Ma}$ (Early Zanclean) and calculate total subsidence rates of respectively $49 \mathrm{~m} / \mathrm{Ma}$ at $19 \mathrm{~km}$ from the coast to $241 \mathrm{~m} / \mathrm{Ma}$ at $70 \mathrm{~km}$ from the coast. In other words, the tilt of the shelf is of $0.16 \% / \mathrm{Ma}=0.28 \% / \mathrm{Ma}$ with the rotation point located at $13 \mathrm{~km}$ landward of present day coast. The uncertainty associated with the estimate of subsidence corresponds to errors in the measurements $( \pm 5 \mathrm{~m})$, time-depth conversion, paleomorphology variations, paleobathymetries estimates $( \pm 20 \mathrm{~m})$, sea-level estimation $( \pm 20 \mathrm{~m})$, linear interpolation and dating of first clinoform $\mathrm{p} 1$. We estimated this error to $\pm 45-50 \mathrm{~m}$ for the last $5 \mathrm{Ma}$, i.e. $\pm 15 \mathrm{~m} / \mathrm{Ma}$.

The two methods to estimate subsidence rate are in good agreement.

The value $240 \mathrm{~m} / \mathrm{Ma} \pm 15 \mathrm{~m} / \mathrm{Ma}$ for the last $5.33 \mathrm{Ma}$ is similar to that calculated for the last 500,000 years (250 m/Ma at $70 \mathrm{~km}$ ) (Rabineau et al., 2006). This common value calculated at two very different time scales is in favor of a regular and constant subsidence rate of the outer shelf during the Pliocene-Quaternary. This "total" subsidence is the overall outcome of any processes by which the ground surface has moved (e.g. tectonic, thermal, isostatic effects, compaction...).

- Extrapolating ages of surfaces

As the rate of subsidence is constant through time (but not in space !), we can extrapolate the dating of reflectors between the Messinian (5.33 Ma) and the Upper Quaternary (MIS12) on the shelf. q10 surface is dated around $1 \mathrm{Ma}$ and p11 around $2.7 \mathrm{Ma}$. 
4.2.2. Calculation of Pliocene-Quaternary Subsidence rates from the upper slope to the deep Basin

The base of salt surface (Fig. 9), shows two different segments: a tilted part (between Km 120 and 180 from the Coast) and a nearly flat surface around $5.6 \mathrm{~km}$ depth from $\mathrm{Km} 180$ to the very deep basin. We therefore define another hinge point at $\mathrm{Km} 180$ and fit a line through the upper part. The bestfit straight line is interpolated between a point located at ESP 201 (90 km of present coastline (at the change of direction of the profile) to $\mathrm{Km} 180$ from coastline. The slope of this surface compared to horizontal is $1.44^{\circ}$ or $2.5 \%$ (Fig. 9). Some salt has been deposited on this surface as indicated by the existence of a few small pillows of salt that can still be observed while most of the salt has moved creating the well-known salt tectonic and diapirs in the basin (Gaullier, 1993; Dos Reis, 2001; Dos Reis et al., 2004). Fig. 10 shows a perpendicular strike line (see location on Fig. 1) which also shows a tilt of the base of slope from NE towards the SW. As previously stated, the salt is always deposited as flat horizontal layers. Present Day slope of the salt paleo-layer therefore measures directly the amount of post-depositional subsidence. The exact dating of the base of salt in the deep basin is still a matter of strong debate because no samples are available. We used an average date for the initiation of massive salt deposition at $5.7 \mathrm{Ma}( \pm 0.25 \mathrm{Ma})$ (see previously) which gives $0.25^{\circ} / \mathrm{Ma}$ for the last 5.7 Ma. At Km 180 from the Coast (202 km from the rotation point), the maximum total rate of subsidence would be (as shown in figure 2) $O A^{*} \tan \beta=202000^{*} \tan \left(1.44^{\circ}\right) / 5.7=890 \mathrm{~m} / \mathrm{Ma}$ over $5.7 \mathrm{Ma}( \pm 40 \mathrm{~m} / \mathrm{Ma})$. Note that the difference in subsidence rate in the two most extreme scenarios for the dating of salt deposition remains small.

In the deepest part of the basin (from Km 180 around ESP204) the base of salt is clearly imaged on profiles below the transparent layer) (Fig. 9) and shows a sub-horizontal surface very gently dipping from $5.2 \mathrm{~s}$ twtt $(5.6 \mathrm{~km})$ at Km180 to a maximum of $5.4 \mathrm{~s}$ twtt around $41^{\circ} 30^{\prime}$ which corresponds to a depth around $6 \mathrm{~km}$ at $270 \mathrm{~km}$ from the coast. The average dip of this surface is therefore around $0.005 \%$ or $0.003^{\circ}$. We have an additional subsidence of the deepest central part of the basin of $70 \mathrm{~m} / \mathrm{Ma}$ compared to the $\mathrm{Km} 180$ point, i.e. $960 \mathrm{~m} / \mathrm{Ma}$ over the last $5.7 \mathrm{Ma}( \pm 40 \mathrm{~m} / \mathrm{Ma})$. In the deepest part of the basin, all potential postdepositional movements of the margin have been nearly vertical as the base of salt remained nearly horizontal in this domain.

Between $\mathrm{Km} 62$ and $\mathrm{Km} \mathrm{110-120} \mathrm{from} \mathrm{the} \mathrm{coastline,} \mathrm{another} \mathrm{sedimentary} \mathrm{paleo-marker} \mathrm{has}$ been identified: a planar surface of erosion found in the entire Gulf of Lion (Bache et al. 2009, 2012) (purple reflector in Fig. 11) and followed down to the Catalan margin (Garcia et al., 2011). This surface can be followed easily at least down to $2.6 \mathrm{~s}$ twtt around $\mathrm{Km} \mathrm{110.} \mathrm{It} \mathrm{has} \mathrm{been}$ interpreted as a transgressive ravinement surface (RS) that erodes the previous Messinian regressive erosional surface and its lowstand deposits (the detritic fans) and occurs at the end of the Messinian Salinity Crisis (MSC), before the very rapid transgression (i.e. the reflooding). The landward termination of the surface (the position of the shoreline before the final rapid transgression) lies at $1.6 \mathrm{~s}$ twtt, which corresponds to a depth of $1800-2100 \mathrm{~m}$ on Profile LRM16-Ligo20 (using velocities from wells Bache et al., 2012). The constant depth of this paleoshoreline demonstrates, again, that Pliocene-Quaternary subsidence has been homogeneous in the central part of the margin.

\subsection{Measurements of isostatic rebound}

Wells on the shelf showed that the Upper Miocene deposits are very shallow (Cravatte et al., 1974), with brackish to inner shelf environment in both Mistral and Tramontane) while in Autan1 
(which is located much further on the upper slope) paleoenvironments are described as inner to middle shelf most probably deposited as near horizontal strata, by analogy to present day situation. However, the Miocene strata underneath the Messinian erosional surface appear today, in the middle-shelf area, also as planar and parallel to each other (e.g on Fig. 3 from Km 26 to $\mathrm{Km} \mathrm{66)}$. The Pliocene and Quaternary subsidence, which reaches $250 \mathrm{~m} / \mathrm{Ma}$ at shelf break, should have tilted them, as we have shown and calculated for Pliocene-Quaternary reflectors, which is not what we observe. Miocene strata must have been deformed before the deposition of Pliocene-Quaternary layers. Many authors (Gorini et al., 2005; Mauffret et al., 2001; Norman and Chase, 1986; Ryan, 1976; Ryan, 2011), have proposed the existence of a deformation in relation to an isostatic re-adjustement of the margin related to the Messinian erosional and salinity crisis. The drop of sea-level, the intense erosion on the shelf (over 1.5s twtt of sediments have been eroded in this area (Bache, 2008; Bache et al. 2009) must have induced an isostatic rebound of the shallow margin. On the other hand, the deposition of the LU, MU and UU that reach over $3000 \mathrm{~m}$ thick in the deep basin according to Bache et al., (2009, 2012) induce overweight that overwhelm the loss of water, and must have induced an isostatic increase of gravitational subsidence. Our results on Pliocene-Quaternary subsidence combined with the observation of Miocene geometries, give a direct estimate of this rapid isostatic rebound on the shelf: Miocene strata must have been uplifted during the MSC and then subsided again during the Pliocene-Quaternary. As they are back to horizontal at present day, the amount of uplift during the crisis, therefore equals the amount of Pliocene-Quaternary subsidence (i.e. $1280 \mathrm{~m}$ at $70 \mathrm{~km}$ ). We can therefore quantify the isostatic rebound during the crisis as equal to $1.3 \mathrm{~km}$ in this area on the outer shelf.

This value is of the same order than that evaluated by Mauffret et al., (2001) who found $1.7 \mathrm{~km}$ of uplift in the offshore part of the Albères Massif (i.e. about $20 \mathrm{~km}$ south of our estimate near the Pyrenees) which is not fully compensated by Pliocene-Quaternary subsidence as the landward dipping geometry of the strata on the outer shelf demonstrate. Considering the duration of the crisis to be 700,000 years at the most (CIESM, 2008), we found a very high rate of more than $1830 \mathrm{~m} / \mathrm{Ma}$ of uplift. This value is minimal as the duration of the maximum drop and reflooding is less than 700, 000 years. It applies on the outer shelf only, the amount is less on the middle shelf and does not apply in the deep basin as deposition of large detritics and evaporites would instead enhance subsidence.

\section{Discussion: Tectonic and Geodynamic implications: deformation and isostatic rebound}

\subsection{Deformation and segmentation of the margin}

The detailed interpretation of surfaces enabled us to demonstrate a small but visible deformation in the inner part of the shelf. The position of the break in slope induced by the deformation coincides with the position of major pre-Messinian faults as mapped by Mauffret et al. (2001), Gorini et al. (2005) and Bache (2008) (F1 fault in Fig. 8A and B). Dating of the surfaces enabled us to date this deformation slightly before $1 \mathrm{Ma}$.

Apart from this small deformation, our results divide the margin in three parts:

1) The shelf shows a tilt of $0.18 \% \mathrm{Ma}$, with a rotation point (hinge point) $13 \mathrm{~km}$ landward of the coast on LRM18. This rotation point is somewhat different than that calculated for the last 500,000 years that was found at $13 \mathrm{~km}$ seaward of the coast (Rabineau et al., 2006). 
This difference can be explained by the deformation occurring at $1 \mathrm{Ma}$ which uplifts the inner part of the shelf, this would have prevented deposition of younger strata on the inner shelf and shifted depocentre $30 \mathrm{~km}$ seaward resulting in a pinch-out of Quaternary sequences and surfaces at $13 \mathrm{~km}$ offshore from the coast from this period (1 Ma) to present day. Position of this rotation point must be further investigated in 3D and compared to onshore studies. (Viallard and Gorini, 1994) for example suggested the existence of recent gravitational structure onshore that may be related to the post-rift tilting of the margin.

2) On ECORS NW-SE, from 120 to $180 \mathrm{~km}$ from the coast, the slope subsides with a rate of $0.25^{\circ} / \mathrm{Ma}$. This area of strong tilt on the slope is located in the domain II of highly thinned continental crust just above the T-reflector described by De Vogt et al. (1991).

3) In the deep basin, an abrupt change of the subsidence occurs around $\mathrm{Km} 180$ (on ECORS profile, Fig. 9): the subsidence of the margin is nearly vertical allowing the preservation of a tabular base of salt. The value of total subsidence may have reach up to $960 \mathrm{~m} / \mathrm{Ma}( \pm 40 \mathrm{~m} / \mathrm{Ma})$ in the center of the Basin. The point at $180 \mathrm{~km}$ falls at the limit of the Domain III, which decribes the "undetermined crust" between the strongly thinned continental crust domain II and the oceanic crust domain IV (Bache et al., 2010) (Fig. 9). Further studies and modelling will need to investigate the detailed relation between these observations and the relation between the basin fill and the structure of the underlying lithosphere such as discussed by Kooi et al., 1992. Such high and vertical subsidence rates in the centre of the basin have also been observed in much older open ocean, like the South Atlantic (Moulin et al., 2005; Aslanian et al., 2009) leading to new non-conservative models for the evolution of margins (Aslanian et al., 2009; Bache et al., 2010).

\subsection{Isostasy}

The amplitude of isostatic uplift measured on the outer shelf $1.8 \mathrm{~km} / \mathrm{Ma}$ or $1.8 \mathrm{~mm} / \mathrm{yr}$ is of the same order of magnitude than the recent glacio-isostatic uplift measured in areas that have been submitted to the maximum ice-sheet thickness in the Northern Hemisphere, e.g. $300 \mathrm{~m}$ for the deglaciation (the last circa $20 \mathrm{ka}$ ) (Ehlers and Gibbard, 2004a), i.e an average rate of 1.5 $\mathrm{mm} / \mathrm{yr}$ or $1.5 \mathrm{~km} / \mathrm{Ma}$. This value is also close to the present day vertical motion of $1.1 \mathrm{~mm} / \mathrm{yr}$ $(1.1 \mathrm{~km} / \mathrm{Ma})$ measured in the southern Valais, in the Alps for which $50 \%$ of the value has been related to the increase in erosion rates and isostatic rebound since the last $1 \mathrm{Ma}$ (Champagnac et al., 2007). Norton \& Hampel (2010) suggested that the deglaciation in the Alps caused about $128 \mathrm{~m}$ of isostatic rebound between 21 and $13 \mathrm{ka}$, i.e. $16 \mathrm{~m} / \mathrm{ka}$ or $16 \mathrm{~km} / \mathrm{Ma}$ (Norton and Hampel, 2010). Other estimations in Ireland suggested a rate of uplift of 150-200 m between 21 and $19 \mathrm{ka} 75-100 \mathrm{~m} / \mathrm{ka}$ or km/Ma (Clark et al., 2004) which are two orders of magnitude greater than our measurement. Direct measurements provided by InSAR new techniques (Satellite Interferometric Synthetic Aperture Radar) to measure the effect of human extensive pumping in water reservoir (Galloway et al., 1998) also show very high values, $40 \mathrm{~m} / \mathrm{ka}$ (e.g. in Las Vegas Valley, Nevada) (Amelung et al., 1999). Therefore the values of $1.8 \mathrm{~m} / \mathrm{ka}(1.8 \mathrm{~km} / \mathrm{Ma})$ suggested here for the extreme Messinian erosional crisis (inducing $1 \mathrm{~km}$ of erosion on the outer shelf and a drop of relative sea-level around $1500 \mathrm{~m}$ ) seems coherent and plausible.

Comparaison to isostatic modelling of the Messinian events in the Mediterranean Sea: The value we found here (1.3 km of isostatic uplift on the outer shelf) is far greater than the values obtained with isostatic modelling by (Govers et al., 2009) in the Mediterranean Sea. Govers described both the effect of the dessication creating an uplift of the margin and the effect of 
evaporites deposition (creating a load) (see his figure 9). But this uplift is limited to 300 to $600 \mathrm{~m}$ (from $100 \mathrm{~km}$ offshore to present-day shoreline), furthermore the uplift is partly compensated by subsidence effect of evaporites deposition. However the model does not take into account the huge amount of erosion on the shelf (more than $1 \mathrm{~km}$ thick, Bache et al., 2009) nor the huge amount of terrigeneous and evaporitic deposits (over $3 \mathrm{~km}$ thick, Bache et al., 2009)..

Kooi et al., (1992) tested several depths of necking and a model of local isostasy in the Gulf of Lion and showed that local isostasy could not account for the present-day configuration of the basin and at the same time reproduced the observed strongly laterally varying bathymetry at the end of rifting, supporting a significant postrift flexural rigidity that must also have a role during the Messinian Isostatic readjuments. We suggest that new runs of isostatic modelling should be undertaken using our new field observations and the different behaviour of the part of the crust of unkown nature.

\section{Conclusions}

The seismic data and interpretation of sedimentary markers and their paleobathymetric significance showed that our studied area subsided regularly without substantial local deformation nor variations in rates since the Zanclean. Subsidence rate increase with increasing distance from the coast. We propose a model for the subsidence with a linear tilt during Pliocene-Quaternary separated into three domains: the shelf, the slope and the deep domain. The amount of total subsidence are high: around $240 \mathrm{~m} / \mathrm{Ma}( \pm 15 \mathrm{~m} / \mathrm{Ma})$ on the outer shelf and up to $960 \mathrm{~m} / \mathrm{Ma}( \pm 40 \mathrm{~m} / \mathrm{Ma})$ in the deepest basin.

The three domains of subsidence seem to coincides with deep structural domain of the margin as described on deep seismic experiments (domains I to IV : continental-thinned-undetermined and oceanic domains): the changes in subsidence rates are located at the limits between domains I-II and II-III, the nearly vertical subsidence occurs from domain III throughout domain IV.

On the contrary, the extreme Messinian event with a huge sea-level drop, ensuing erosion of the shelf and huge amount of deposits in the deep basin induces a very strong isostatic rebound of the margin that was measured for the first time on the outer shelf. This isostatic rebound reaches $1.3 \mathrm{~km}$ in the Aude-Herault outer shelf during the Messinian (i.e. $1.8 \mathrm{~km} / \mathrm{Ma}$ with a 0.7 Ma duration for the crisis).

This work needs to be further extended in space to provide a full 3D description of subsidence history of the margin.

\section{Acknowledgements}

This work was initiated with $\mathrm{J}$-L Olivet (Ifremer) who greatly contributed to the initial interpretations and results on LRM18. The velocity model and time-depth conversion of LRM18 profile was made with the help of $\mathrm{H}$. Nouzé (previously at Ifremer). Velocities in wells were computed from sonic logs by S. Maquine de Souza. 
Seismic data were interpretated with the help of Kingdom Suite software. The final manuscript greatly benefited from the comments and advices from the anonymous reviewers. We also thank Pascal Le Roy, Cécile Robin, for discussion and a critical pre-review of the paper; Brigitte Van Vliet Lanoë and Samuel Toucanne for discussion on Quaternary isostatic rebound. This research was mainly funded by CNRS and IFREMER, with additional support from the French Actions-Marges and CNRS-INSU SYSTER and TERMEX program. This work also benefited from a State Grant from the French Agence Nationale de la Recherche (ANR) in the Program « Investissements d'avenir » with the reference ANR-10-LABX-19-01, Labex Mer. TOTAL (JeanLoup Rubino) and Melrose Ressources (Richard Bunt, Eric Lalande) are also acknowledge for providing access to seismic data.

\section{Figures Captions}

Fig. 1

Location of the study area, dataset and bathymetry of the Gulf of Lion (modified from (Berné et al., 2002). Red triangles correspond to industrial wells. Blue triangles correspond to the two PROMESS European boreholes. Big green dots represent the ESP data, small green dots represent OBS data on Sardinia profiles. Thick black lines correspond to seismic lines shown in this paper. The thick purple line represents the end of the smooth surface (at $1.6 \mathrm{~s} \mathrm{twtt)}$ and the pink thick line represents the limit of salt (from Bache, 2008; Bache et al., 2009, 2012).

Fig. 2

Definition of Accommodation or relative sea-level

A) Accommodation is a function of Subsidence and Eustatism, it does not depend on sedimentary fluxes, nor hydrodynamics or autogenic factors.

Accommodation $=$ Subsidence + Eustatism

Accommodation $=$ Thickness $(e)+$ Bathymetry $(b)$

Dots represent offlap break (inflexion point between topset and foreset) and toeset break (inflexion point between foreset and bottomset).

B) Example of accommodation variation between $\mathrm{t} 1$ and $\mathrm{t} 2$,

Accommodation (Acco i) in each time step (ti) is calculated as the sum of the thickness of sediment (ei) + bathymetry at the top of sediments (bi) at ti (Robin et al., 1996).

$\Delta$ Acco $\left(t_{2}-t_{1}\right)=\operatorname{Acco}\left(t_{2}\right)-A c c o\left(t_{1}\right)=\Delta$ subsi $\left(t_{2}-t_{1}\right)+\Delta$ Eustat $\left(t_{2}-t_{1}\right)=\left(e_{2}+b_{2}\right)-\left(e_{1}+b_{1}\right)$

Where $e_{1}$ and $e_{2}$ represent the thicknesses of the sediment at time $t_{1}$ and $t_{2}$

And $b_{1}$ and $b_{2}$, the bathymetries, positive below sea-level 
Variation in Accommodation is positive when new space is created (either by subsidence or by eustatism (sea-level rise) or both). Eustat is positive if sea-level is above present day sea-level; $\Delta$ Eustat is positive if sea-level rises between $\mathrm{t} 1$ and $\mathrm{t} 2$.

In this example there is no subsidence so variation of accommodation are solely due to increase in sea-level. Note that, resulting geometry does not depend only on accommodation variations but also on sediment fluxes and hydrodynamic in the basin. In case B) for example, the observed geometry implies a high sediment flux between $\mathrm{t} 1$ and $\mathrm{t} 2$.

C) Calculation of the angle of subsidence $(\alpha)$ line.

\section{Fig. 3}

Seismic Profile LRM18 in TWTT (s) and interpretation of prograding clinoforms. Wells Tramontane (TR) and Rascasse (RA) are projected on the profile. Shelf-offlap breaks, slopetoeset breaks and LGM shoreline break have been identified on profile. Key reflectors are labelled and highlighted in colors MES (pink), p11 (green), q10 (red), D30 (yellow) and seafloor. Location of Fig. S1 (Supplementary data) (zoom) is also shown.

\section{Fig. 4}

Interpretative line drawing of Profile ECORS NW-SE in TWTT (s) (modified from (Olivet, 1996); Bache, 2008; Bache et al., 2009; Bache et al., 2010). The names of Messinian surfaces and units are adapted from Lofi et al. (2011) but their position and thicknesses are from Bache et al., 2009.

Thick lines represent respectively from deepest to shallowest : base of continental crust (CC), top of substratum (S), basal Messinian erosional surface BES (in red) and its correlative conformity BS in the deepest basin, base of probable early Messinian turbidites (LU0), base of presumed evaporates-detritic alternation in blue (LU1); margin Messinian erosional surface (MES in pink), Messinian transgressive surface (in purple); base and top of salt (MU), and seafloor.

Fig. 5

A) and B) Interval velocities ( $\mathrm{m} / \mathrm{s}$ ) measured in TRAMONTANE and RASCASSE wells positioned on dip-profile LRM16 and LRM10 (see location on Fig. 1).

Main reflectors have been identified: D30 (434,000 ka); q10 (around 1 Ma); p11 (around $2.7 \mathrm{Ma})$ and the Messinian margin erosional surface MES (5.3 Ma) (in pink) and Miocene reflector (light green) below the Messinian erosional surface on LRM16 (see age estimates in discussion). Note on LRM10, a paleo-canyon cut along its course (in orange) and sealed by the q10 erosional surface; and on LRM16, the presence of a fault that offsets the light green Miocene reflector (from Bache, 2008).

In dark green, nice clinoforms are developed with topsets, forsets and bottomsets, the last clinoform of this package is the Pxx surface as interpreted by Leroux (2012). Below the blue reflector, reflexions are sub-plane and correspond to bottomsets of previously deposited clinoforms (such as p11). 
C) 2D evolution of velocities based on wells Tramontane and Rascasse projected on Profile LRM18 (see Fig. 1 for location). Envelopes for velocity intervals are based on geometries of deposits as observed on seismic profiles (velocities appeared to change from topsets to foresets and bottosets). Note also that those limits are not time-lines but related to major lithology changes. Within envelopes, interval velocities show linear variations and jumps at interfaces. Note also that extrapolation towards upper-slope is subject to caution as the evolution of velocities might be very different (in particular due to the presence of canyons).

D) Velocity model used for time-depth conversion using velocities as measured on ESP data (Pascal et al., 1993) and Sardinia data (Gailler et al., 2009) together with velocities as measured in GLP2 well (in red) and simplified (Leroux, 2012).

\section{Fig. 6}

Seismic Profile LRM18 in depth $(\mathrm{m})$ used for calculation of 1D accommodation and subsidence at points $A$ et B. Black pins on top show cross-lines. Wells Tramontane and Rascass are projected on the profile.

Initial accommodation corresponds to early Pliocene stage. Final accommodation corrresponds to present-day stage. Here we considered that offlap breaks represent the shelf breaks with a constant paleowater depth approximated to $150 \mathrm{~m}$. Eustatism at initial stage (early Pliocene) is considered to be between 40 and $70 \mathrm{~m}$ (Haq et al., 1987), we used $50 \mathrm{~m}$ in this estimate. Eustatism at final stage (present-day) is equal to $0 \mathrm{~m}$. Accomodation has been estimated by measuring the height of p2 foreset (between offlap breaks and toeset breaks; 650 at point A) which corresponds to the minimal space that enables clinoform deposition; we added to this value the paleo-water depth of the offlap break $(150 \mathrm{~m})$ as Accomodation = Eustatism + Subsidence. The rate of subsidence is calculated using a duration for Pliocene-Quaternary of 5.33 Ma (occurring after the Messinian Salinity Crisis).

\section{Fig. 7}

Seismic Profile LRM18 in depth $(\mathrm{m})$ used for calculation of 2D subsidence along the profile. The inner part of the shelf (from 0 to $36 \mathrm{~km}$ ) has been reconstructed to correct the effect of postdepositional deformation (large scale deformation). In this configuration, topsets of reflectors $\mathrm{p} 1$ to present-day sea-floor are well approximated to straight lines both on the inner and outer part of the shelf. All lines are inclined seaward, their inclinations increase with the age of reflectors. All lines have also a common rotation point which is located $13 \mathrm{~km}$ landward of present-day coast. The tilting of the margin from p1 to present day can be measured directly on the profile, it reaches $1280 \mathrm{~m}$ at $\mathrm{Km} 70$ from the coast. Considering that the first clinoform p1 can be dated as Early Pliocene (just after the Zanclean reflooding) we estimated its age between 5.3 and 5 $\mathrm{Ma}$. This allows to calculate a subsidence rate going from $0 \mathrm{~m} / \mathrm{Ma}$ at $-13 \mathrm{~km}$ landward of the coast to $241 \mathrm{~m} / \mathrm{Ma}$ at $70 \mathrm{~km}$ seaward from the coast (near the upper slope).

\section{Fig. 8}

A) Zoom on Seismic Profile LRM16 in TWTT (s) and interpretation of Miocene and Pliocene-Quaternary strata. Wells Tramontane is on the profile. Note the deformation of p11 reflector and q10 reflector just above a major deeper fault F1. Interpretation of Miocene strata slightly modified from Bache (2008). Another deformation can be suspected in the landward-most part of the profile. See position of profile and faults on Fig. 8B. 
B) Mapping of major faults and thickness of Miocene deposits (without Messinian deposits) (in s twtt) from Bache (2008). The thick black line represents the position of seismic profile LRM16 shown in A). Major fault F1 is localised near the Tramontane well (red triangle) on the profile. Also shown on the map are the limits between domain I (continental crust), domain II (thinned continental crust or necking zone), domain III (transitional zone) and domain IV (oceanic crust) (see also Fig. 9).

\section{Fig. 9}

A) ECORS profile converted in depth (using previous velocity law as shown in Fig. 5). BES: discontinuity at the base of Messinian deposits; LU0, LU1: lower units of Messinian age; MU: mobile unit (salt). For a more detailed interpretation of Miocene and Messinian deposits see recently published paper from Bache et al. (2009); Bache et al. (2010). The vertical dashed red line indicates a change in the direction of the seismic profile. B) Approximation of the Messinian surface to the base of salt with a straight line inclined seaward. We limited the line with a rotation point located $90 \mathrm{~km}$ seaward of present-day coast when the profile changes direction.

\section{Fig. 10}

Seismic Profile RM01-107 (Courtesy Melrose Resources) in TWTT (s) (see location on figure 1) and interpretation of Pliocene-Quaternary deep-sea fan deposits. Black pins on top show crosslines, Well GLP 2 is projected on the profile.

Units 1, 2, 3 correspond respectively to Lower, Intermediate and Upper Series, as identified in (Droz et al., 2006). q10 (in red) and P11 (in green) represent major erosion boundaries respectively between Series $1-2$ and Series 2-3. Stratigraphic interpretation from the shelf correlated to the deep sea suggest ages of $2.7 \mathrm{Ma}$ for P11 and $1 \mathrm{Ma}$ for q10 (see discussion). Thin red lines are local erosion unconformities; pink bodies are local or regional MTDs.

Differential subsidence is imaged by the inclination of the base of salt deposit (in pink). Local deformation, pull-downs can be observed below canyons, they are artefact due low water velocities in canyons compared to adjacent sediments. Note that the general westward inclination is also observed in underlying deposits (yellow reflectors).

\section{Supplemenary data Fig. $\mathbf{S 1}$}

Seismic Profiles with three different resolution but located at the same place and plotted with the same horizontal and vertical scales. A) Sparker profile 1049 from BASAR1 cruise; B) Multichannel high resolution profile SMAVH07 and C) conventionnal industrial LRM18 (TOTAL), all with their respective frequency spectrum. The distance between P1049 and SMAVH07 is less than $100 \mathrm{~m}$; distance between SMAVH 07 and LRM18 is less than 1 kilometer. Note that the combination of profiles from different resolution enables to follow and recognise sedimentary structures on the different scales. For example here the Last Glacial Maximum (LGM) sandy prism (red dot) clearly imaged on Sparker data (with highly dipping reflectors) can just be guessed on the LRM. 


\section{Supplementary data Fig. S2}

(A) Seismic Profile LRM18 in depth $(\mathrm{m})$ used for calculation of 2D subsidence along the profile. Topsets of reflectors 11 to present day sea-floor are well approximated to straight lines on the outer part of the shelf (from Km36 to Km70). Lines are inclined seaward, inclination increases with the age of reflectors. All lines have a common rotation point which is located $13 \mathrm{~km}$ landward of present-day coast.

(B) Zoom showing the misfit of those lines in the inner part of the shelf. Note how reflectors $\mathrm{p} 11$ to $\mathrm{p} 14$ are deformed (around $\mathrm{Km} 32$ ).

\section{References}

Allen, P.A., Allen, J.R., 1990. Basin Analysis: Principles and Applications. Blackwell Scientific Publications, Oxford, $451 \mathrm{pp}$.

Allen, P.A., Allen, J.R., 2005. Basin Analysis: Principles and Applications. Blackwell Publishing Company, Oxford, 549 pp.

Aloïsi, J.C., 1986. Sur un modèle de sédimentation deltaïque: contribution à la connaissance des marges passives. Université de Perpignan, Perpignan, 162 pp.

Amblas, D., Gerber, T.P., De Mol, B., Urgeles, R., Garcia-Castellanos, D., Canals, M., Pratson, L.F., Robb, N., Canning, J., 2012. Survival of a submarine canyon during long-term outbuilding of a continental margin. Geological Society of America 40, 543-546.

Amelung, F., Galloway, D.L., Bell, J.W., Zebker, H.A., Laczniak, R.J., 1999. Sensing the ups and downs of Las Vegas-InSAR reveals structural control of land subsidence and aquifersystem deformation. Geology 27, 483-486.

Aslanian, D., Moulin, M., Olivet, J.L., Unternehr, P., Matias, L., Bache, F., Rabineau, M., Nouzé, H., Klingelhoefer, F., Contrucci, I., Labails, C., 2009. Brazilian and African passive margins of the Central Segment of the South Atlantic Ocean: Kinematic constraints. Tectonophysics 468, 98-112.

Aslanian, D., Rabineau, M., Klingelhoefer, F., Moulin, M., Schnurle, P., Gailler, A., Bache, F., Leroux, E., Gorini, C., Droxler, A., Eguchi, N., Kuroda, J., Alain, K., Roure, F., Haq, B., 2012. Structure and evolution of the Gulf of Lions: The Sardinia seismic experiment and the GOLD (Gulf of Lions Drilling) project. The Leading Edge 31, 786-792.

Bache, F., 2008. Evolution Oligo-Miocène des marges du micro océan Liguro Provençal. Thèse de Doctorat, Université de Brest et IFREMER, http://www.ifremer.fr/docelec

Bache, F., Olivet, J. L., Gorini, C., Rabineau, M., Baztan, J., Aslanian, D., and Suc, J. P., 2009. The Messinian Erosional and Salinity Crises: View from the Provence Basin (Gulf of Lions, Western Mediterranean). Earth Planet. Sci. Lett. 286, 139-157.

Bache, F., Olivet, J.-L., Gorini, C., Aslanian, D., Labails, C., Rabineau, M., 2010. Evolution of rifted continental margins: the case of the Gulf of Lions (Western Mediterranean Basin). Earth and Planetary Science Letters 292, 345-356.

Bache, F., Popescu, S.-M., Rabineau, M., Gorini, C., Suc, J.-P., Clauzon, G., Olivet, J.-L., Rubino, J.-L., Melinte-Dobrinescu, M.C., Estrada, F., Londeix, L., Armijo, R., Meyer, B., Jolivet, L., Jouannic, G., Leroux, E., Aslanian, D., Reis, A.T.D., Mocochain, L., Dumurdžanov, N., Zagorchev, I., Lesić, V., Tomić, D., Namik Çağatay, N., Brun, J.-P., Sokoutis, D., Csato, I., Ucarkus, G., Çakir, Z., 2012. A two-step process for the reflooding of the Mediterranean Basin after the Messinian Salinity Crisis. Basin Research 24, 125-153.

Bassetti, M.A., Berné, S., Jouet, G., Taviani, M., Dennielou, B., Flores J. A., Gaillot, A., Gelfort, R., Lafuerza, S., Sultan, N., 2008. The 100-ka and rapid sea level changes recorded by 
prograding shelf sand bodies in the Gulf of Lions (western Mediterranean Sea). Geochem. Geophys. Geosyst. 9, 1-27.

Bassetti, M.A., Jouet, G., Dufois, F., Berné, S., Rabineau, M., Taviani, M., 2006. Sand bodies at the shelf edge in the Gulf of Lions (Western Mediterranean): Deglacial history and modern processes. Mar. Geol. 234, 93-109.

Baztan, J., Berné, S., Olivet, J.-L., Rabineau, M., Aslanian, D., Gaudin, M., Rehault, J.-P., Canals, M., 2005. Axial incision: The key to understand submarine canyon evolution (in the western Gulf of Lion). Mar. Pet. Geol. 22, 805-826.

Berné, S., Aloïsi, J.C., Baztan, J., Dennielou, B., Droz, L., Dos Reis, T., Lofi, J., Méar, Y., Rabineau, M., 2002. Notice de la carte morpho-bathymétrique du Golfe du Lion. IFREMER et Région Languedoc Roussillon, Brest, p. 48.

Berné, S., Rabineau, M., Flores, J.A., Sierro, F.J., 2004. The Impact of Quaternary Global Changes on Strata Formation. Oceanography 17, 92-103.

Bessis, F., 1986. Some remarks on the study of subsidence of sedimentary basins: application to the Gulf of Lions margin (Western Mediterranean). Mar. Pet. Geol. 3, 37-63.

Blackwelder, B.W., 1981. Late cenozoic marine deposition in the united States Atlantic coastal plain related to tectonism and global climate. Palaeogeography, Palaeoclimatology, Palaeoecology 34, 87-114.

Burrus, J., 1989. Review of geodynamic models for extensional basins; the paradox of stretching in the Gulf of Lions (northwest Mediterranean). Bull. Soc. Geol. Fr. 8, 377-393.

Burrus, J., Audebert, F., 1990. Thermal and Comparaison Processes in a young rifted basin containing evaporites: Gulf of Lions, France. The American Association of Petroleum Geologists Bulletin 74, 1420-1440.

Burrus, J., Bessis, F., Doligez, B., 1987. Heat flow, subsidence and crustal structure of the Gulf of Lions (NW Mediterranean): a quantitative discussion of the classical passive margin model, in: Beaumont, C., Tankard, A. (Eds.), Sedimentary Basins and Basins Forming Mechanisms. CSPG Memoir 12.

Canals, M., Danovaro, R., Heussner, S., Lykousis, V., Puig, P., Trincardi, F., Calafat, A.M., de Madron, X.D., Palanques, A., Sanchez-Vidal, A., 2009. Cascades in Mediterranean submarine grand canyons. Oceanography 22, 26-43.

Cattaneo, A., Correggiari, A., Langone, L., Trincardi, F., 2003. The late-Holocene Gargano subaqueous delta, Adriatic shelf: Sediment pathways and supply fluctuations. Mar. Geol. 193, 61-91.

Cattaneo, A., Trincardi, F., Asioli, A., Correggiari, A., 2007. The Western Adriatic shelf clinoform: energy-limited bottomset. Cont. Shelf Res. 27, 506-525.

Chamot-Rooke, N., Gaulier, J.M., Jestin, F., 1999. Constraints on Moho depth and crustal thickness in the Liguro-Provençal basin from a 3D gravity inversion: geodynamic implications. In: Durand, B., Jolivet, L., Horvàth, F., Séranne, M. (Eds.), Spec. Publ.-Geol. Soc. Geological Society, London, pp. 37-62.

Champagnac, J., Molnar, P., Anderson, R.S., Sue, C., Delacou, B., 2007. Quaternary erosioninduced isostatic rebound in the western Alps. Geology 35, 195-198.

CIESM, 2008. The Messinian Salinity Crisis from mega-deposits to microbiology- A consensus report. CIESM workshop Monograph (F. Briand, Ed.) № 33, 1-26.

Clark, P.U., McCabe, A.M., Mix, A.C., Weaver, A.J., 2004. Rapid Rise of Sea Level 19,000 Years Ago and Its Global Implications. Science 304, 1141-1144.

Cloething, S., Kooi, H., 1992. Tectonics and Global Changes-inferences from Late Cenozoic subsidence and uplift patterns in Atlantic/Mediterranean region. Terra Nova 4, 340-350.

Cravatte, J., Dufaure, P., Prim, M., Rouaix, S., 1974. Les sondages du Golfe du Lion: Stratigraphie, Sédimentologie. Compagnie Française des Pétroles, Paris, 274 pp.

De Voogd, B., Nicolich, R., Olivet, J.L., Fanucci, F., Burrus, J., Mauffret, A., Pascal, G., Argnani, A., Auzende, J.M., Bernabini, M., Bois, C., Carmignani, L., Fabbri, A., Finetti, I., Galdeano, A., 
Gorini, C.Y., Labaume, P., Lajat, D., Patriat, P., Pinet, B., Ravat, J., Ricci Lucchi, F., Vernassa, S., 1991. First deep seismic reflection transect from the Gulf of Lions to Sardinia (ECORSCROP profiles in Western Mediterranean), in: Meissner, R. (Ed.), Continental Lithosphere: Deep seismic reflections. American Geophysical Union, pp. 265-274.

Dos Reis, T., 2001. La Tectonique Salifère et son influence sur l'Architecture Sédimentaire Quaternaire de la Marge du Golfe du Lion-Méditerranée Occidentale. Doctorat, Université de Paris 6, Paris, $216 \mathrm{pp}+157 \mathrm{pp}$.

Dos Reis, T.A., Gorini, C., Mauffret, A., Mepen, M., 2004. Stratigraphic architecture of the Pyreneo-Languedocian submarine fan, Gulf of Lions, western Mediterranean Sea. C.R. Geoscience 336, 125-133.

Droz, L., Dos Reis, A., Rabineau, M., Berné, S., Bellaiche, G., 2006. Quaternary turbidite systems on the northern margins of the balearic basin (western mediterranean) : a synthesis. Geo.Mar. Lett. 26 (6), 347-359.

Dupré, S., Bertotti, G., Cloetingh, S., 2007. Tectonic history along the South Gabon Basin: Anomalous early post-rift subsidence. Mar. Pet. Geol. 24, 151-172.

Ehlers, J., Gibbard, P., 2004a. Quaternary Glaciations - Extent and Chronology, Part 1 : Europe. Developments in Quaternary Science, Elsevier, Amsterdam 2a.

Emery, D., Myers, K., Bertram, G., Griffiths, C., Milton, N., Reynolds, T., Richards, M., Sturrock, S., 1996. Sequence Stratigraphy. Blackwell Science Ltd, Oxford, 297 pp.

Gailler, A., Klingelhoefer, F., Olivet, J. L., Aslanian, D., 2009. Crustal structure of a young margin pair: New results across the Liguro-Provencal Basin from wide-angle seismic tomography. Earth Planet. Sci. Lett. 286, 333-345.

Galloway, D.L., Hudnut, K.W., Ingebritsen, S.E., Philips, S.P., Peltzer, G., Rogez, F., Rosen, P.A., 1998. Detection of aquifer system compaction and land subsidence using interferometric synthetic aperture radar, Antelope Valley, Mojave Desert, California. Water Resources Res. 34, 2573-2585.

Garcia, M., Maillard, A., Aslanian, D., Rabineau, M., Alonso, B., Gorini, C., Estrada, F., 2011. The Catalan margin during the Messinian Salinity Crisis, Physiography, morphology and sedimentary Record, Marine Geology, Volume 284, Issues 1-4, 1 June 2011, Pages 158-174

Gaudin, M., Berné, S., Jouanneau, J.-M., Palanques, A., Puig, P., Mulder, T., Cirac, P., Rabineau, M., Imbert, P., 2006. Massive sand beds attributed to deposition by dense water cascades in the Bourcart canyon head, Gulf of Lions (northwestern Mediterranean Sea). Mar. Geol. 234, 111-128.

Gaullier, V., 1993. Diapirisme salifère et dynamique sédimentaire dans le bassin liguroprovencal: données sismiques et modèles analogiques. Université Pierre et Marie Curie, Paris, 327 pp.

Gorini, C., Lofi, J., Duvail, C., Dos Reis, T., Guennoc, P., Le Strat, P., Mauffret, A., 2005. The Late Messinian salinity crisis and Late Miocene tectonism: interaction and consequences on the physiography and post-rift evolution of the Gulf of Lions margin. Mar. Pet. Geol. 22, 695712.

Gorini, C., Mauffret, A., Guennoc, P., Le Marrec, A., 1994. Structure of the Gulf of Lions (Northwestern Mediterranean Sea), in: Mascle, A. (Ed.), Hydrocarbon and Petroleum Geology of France. Springer-Verlag, Berlin, pp. 223-243.

Govers, R., Meijer, P., Krijgsman, W., 2009. Regional isostatic response to Messinian Salinity Crisis events. Tectonophysics 463, 109-129.

Guennoc, P., Gorini, C., Mauffret, A., 2000. Histoire géologique du Golfe du Lion et cartographie du rift oligo-aquitanien et de la surface messinienne. Géologie de la France 3, 67-97.

Guillocheau, F., 1991. Modalités d'empilement des séquences génétiques dans un bassin de plate-forme (Dévonien Armoricain) : nature et distorsion des différents ordres de séquences de dépôts emboîtées. Bull. Centres Rech. Explor.-Prod. Elf-Aquitaine 15, 383-410. 
Haq, B.U., Hardenbol, J., Vail, P., 1987. Chronology of fluctuating sea levels since the Triassic (250 million years ago to present). Science 235, 1156-1167.

Helland-Hansen, W., Hampson, G.J., 2009. Trajectory analysis: concepts and applications. Basin Res. 21, 454-483.

Henriksen, S., Hampson, G.J., Helland-Hansen, W., Johannessen, E.P., Steel, R.J., 2009. Shelf edge and shoreline trajectories, a dynamic approach to stratigraphic analysis. Basin Res. 21, 445-453.

Hsü, K.J., Cita, M.B., Ryan, W.B.F., 1973. The origin of the Mediterranean evaporites, Init. Repts. Deep Sea Drill. Proj. D.C., U.S. Government Printing Office, Washington, pp. 12031231.

Imbrie J., Hays J. D., Martinson D. G., Mclntyre A., Mix A. C., Morley, J. J., Pisias N. G., Prell W. L. \& Shackleton N. J. (1984) - The orbital theory of pleistocene climate : support from a revised chronology of the marine $\delta 180$ record - In Milankovitch and climate ; Berger A., Imbrie J., Hays J., Kukla G., Saltzman B. : 126 : p. 269-305.

Jervey, M.T., 1988. Quantitative geological modelling of siliclastic rock sequences and their seismic expressions, in: Wilgus, C.K., Hastings, B.S., St Kendall, C.G., Ross, C.A., Van Wagoner, J.C. (Eds.), Sea-level changes: an integrated approach. SEPM Special Publication, Tulsa, pp. 47-69.

Jolivet, L., Auger, R., Robin, C., Suc, J.P., Rouchy, J.M., 2006. Lithospheric-scale geodynamic context of the Messinian salinity crisis. Sediment. Geol. 188-189, 9-33.

Kennett, J.P., Hoddell, D.A., 1993. Evidence for relative climatic stability of Antartica during Early Pliocene: A marine perspective. Geogr. Ann. 75 A, 205-220.

Kooi, H., Cloething, S., Burrus, J., 1992. Lithospheric Necking and Regional Isostasy at Extensional Basins. 1. Subsidence and Gravity Modeling With an Application to the Gulf of Lions Margin (SE France). J. Geophys. Res. 97, 17553-17571.

Kooi, H., Cloething, S., 1992. Lithospheric Necking and Regional Isostasy at Extensional Basins 2. Stress-Induced Vertical Motions and Relative Sea Level Changes. J. Geophys. Res. 97, 17573-17591.

Krijgsman,W., Hilgen, F.J., Raffi, I., Sierro, F.J., Wilson, D.S., 1999. Chronology, causes and progression of the Messinian salinity crisis. Nature 400, 652-655.

Labails, C., Olivet, J.-L., Dakhla study group, 2009. Crustal structure of the SW moroccan margin from wide-angle and reflection seismic data (the dakhla experiment) - Part B -the tectonic heritage. Tectonophysics 468, 83-97.

Lastras, G., Canals, M., Urgeles, R., Amblas, D., Ivanov, M., Droz, L., Dennielou, B., Fabrés, J., Schoolmeester S., Akhmetzhanov A., Orange, D., García-García, A., 2007. A walk down the Cap de Creus canyon, Northwestern Mediterranean Sea: Recent processes inferred from morphology and sediment bedforms. Mar. Geol. 246, 176-192.

Le Pichon, X., Pautot, G., Auzende, J.-M., Olivet, J.-L., 1971b. La Méditerranée Occidentale depuis l'Oligocène; schéma d'évolution. Earth Planet. Sci. Lett. 13, 145-152.

Leroux, E., 2012. Quantification des flux sédimentaires et de la subsidence du bassin Provençal, Sciences de la Terre. Université de Brest, 455 pp., http://www.ifremer.fr/docelec.

Lofi, J., Rabineau, M., Gorini, C., Berné, S., Clauzon, G., De Clarens, P., Tadeu Dos Reis, A., Mountain, G.S., Ryan, W.B.F., Steckler, M.S., Fouchet, C., 2003. Plio-Quaternary prograding clinoform wedges of the western Gulf of Lion continental margin (NW Mediterranean) after the Messinian Salinity Crisis. Mar. Geol. 198, 289-317.

Lofi, J., Sage, F., Deverchère, J., Loncke, L., Maillard, A., Gaullier, V., Thinon, I., Gillet, H., Guennoc, P., Gorini, C., 2011. Refining our knowledge of the Messinian Salinity crisis records in the offshore domaine through multi-site seismic analysis. B.S.G.F., 182, 163-180.

Mauffret, A., Durand de Grossouvre, B., Dos Reis, A.T., Gorini, C., Nercessian, A., 2001. Structural geometry in the eastern Pyrenees and western Gulf of Lion (Western Mediterranean). J. Struct. Geol. 23, 1701-1726. 
McKenzie, D.P., 1978. Some remarks on the development of sedimentary basins. Earth Planet. Sci. Lett. 40, 25-32.

Miller, K.G. Michelle A. Kominz, James V. Browning, James D. Wright, Gregory S. Mountain, Miriam E. Katz, Peter J. Sugarman, Benjamin S. Cramer, Nicholas Christie-Blick, and Stephen F. Pekar 2005, The Phanerozoic Record of Global Sea-Level Change. Science, 310 (5752), 1293-1298. [DOI:10.1126/science.1116412]

Miller, K.G., Mountain, G.S., Browning, J.V., Katz, M.A., Monteverde, D.H., Sugarman, P.J., Ando, H., Bassetti, M.A., Bjerrum, C.J., Hodgson, D., Hesselbo, S.P., Karakaya, S., Proust, J.N., Rabineau, M., 2013. Testing sequence stratigraphic models by drilling Miocene foresets on the New Jersey shallow shelf. Geosphere 9, 1-29.

Mitchum, R.M., Vail, P., 1977. Seismic stratigraphic interpretation procedure. In: C.E. Payton (Editor), Seismic stratigraphy - Applications to hydrocarbon exploration. AAPG memoir, 135143.

Mitchum, R.M., Vail, P.R., Thompson, S., 1977a. Seismic stratigraphy and global changes of sea level, part 2: the depositional sequence as a basic unit for stratigraphic analysis, in: Payton, C.E. (Ed.), Seismic stratigraphy - Application to hydrocarbon exploration. AAPG Mem. 26, Tulsa, Oklahoma, pp. 53-62.

Montadert, L., Letouzey, J., Mauffret, A., 1978. Messinian event : seismic evidence, in: Hsü, K.J., Montadert, L. (Eds.), Initial reports of D.S.D.P. Leg 42A. U.S. Government Printing Office, pp. 1037-1050.

Moulin, M., Aslanian, D., Olivet, J.-L., Contrucci, I., Matias, L., Géli, L., Klingelhoefer, F., Nouzé, H., Rehault, J.P., Untemehr, P., 2005. Geological constraints on the evolution of the angolan margin based on reflection and refraction seismic data (ZaïAngo project). Geophys. J. Int. 162, 793-818.

Norman, S.E., Chase, C.G., 1986. Uplift of the shores of the western Mediterranean due to Messinian desiccation and flexural isostasy. Nature 322, 450-451.

Norton, K.P., Hampel, A., 2010. Postglacial rebound promotes glacial re-advances - a case study from the European Alps. Terra Nova 22, 297-302.

Olivet, J.L., 1996. La cinematique de la plaque Iberique. Bulletin des Centres de Recherches Exploration-Production Elf-Aquitaine 20, 131-195.

Pascal G., Mauffret, A., Patriat, P., 1993. The ocean-continent boundary in the gulf of lion from analysis of expanding spread profiles and gravity modelling. Geophys. J. Int. 113, 701-726.

Payton C. E. (1977) - Seismic stratigraphy - applications to hydrocarbon exploitation Amer. Assoc. Petroleum Geol. Memoir 26, Tulsa, Oklahoma, 516 p.

Péron-Pivindic, G., Manatschal, G., 2009. The final rifting evolution at deep magma-poor passive margins from iberia-newfoundland : a new point of view. International Journal of Earth Science 98, 1581-1597.

Posamentier, H.W., Jervey, M.T., Vail, P.R., 1988a. Eustatic controls on clastic deposition I. Conceptual framework, in: Wilgus, C.K., Hastings, B.S., Kendall, C.G.S.C., Posamentier, H.W., Ross, C.A., Van Wagoner, J.C. (Eds.), Sea-Level Changes- an Integrated Approach. SEPM Spec. Pub. 42, Tulsa, pp. 102-124.

Posamentier, H.W., Vail, P.R., 1988b. Eustatic controls on clastic deposition II. Sequences and system tract models, in: Wilgus, C.K., Hastings, B.S., Kendall, C.G.S.C., Posamentier, H.W., Ross, C.A., Van Wagoner, J.C. (Eds.), Sea-Level Changes- an Integrated Approach. SEPM Spec. Pub. 42, Tulsa, pp. 125-154.

Rabineau, M., 2001. Un modèle géométrique et stratigraphique des séquences de dépôts quaternaires de la plate-forme du Golfe du Lion : enregistrement des cycles glacioeustatiques de 100000 ans. Université de Rennes 1, IFREMER and IFP, 392 pp. + 370 pp., http://www.ifremer.fr/docelec. 
Rabineau, M., Berné, S., Aslanian, D., Olivet, J.L., Joseph, P., Guillocheau, F., Bourillet, J.F., Ledrezen, E., Granjeon, D., 2005. Sedimentary sequences in the Gulf of Lion: A record of 100,000 years climatic cycles. Mar. Pet. Geol. 22, 775-804.

Rabineau, M., Berné, S., Ledrezen, E., Lericolais, G., Marsset, T., Rotunno, M., 1998. 3D architecture of lowstand and transgressive Quaternary sand bodies on the outer shelf of the Gulf of Lion, France. Mar. Pet. Geol. 15, 439-452.

Rabineau, M., Berné , S., Olivet J.L., Aslanian, D., Guillocheau, F., Joseph, P., 2006. Paleo sea levels reconsidered from direct observation of paleoshoreline position during Glacial Maxima (for the last 500,00 yr). Earth Planet. Sci. Lett. 252, 119-137.

Rabineau, M.B., S., Olivet J.L., Aslanian, D., Guillocheau, F., Joseph, P., 2007. Corrigendum to: Paleo sea levels reconsidered from direct observation of paleoshoreline position during Glacial Maxima (for the last 500,00 years). Earth Planet. Sci. Lett. 254, 446-447.

Rehault, J.P., Boillot, G., Mauffret, A., 1984. The western Mediterranean Basin geological evolution. Mar. Geol. 55, 445-475.

Robin, C., Guillocheau, F., Gaulier, J.M., 1996. Mesure des signaux eustatiques et tectoniques au sein de l'enregistrement sédimentaire d'un bassin intracratonique. Application au Lias du bassin de Paris. Comptes Rendus de l'Académie des Sciences de Paris 322, 1079-1086.

Ryan, W.B.F., 1976. Quantitative evaluation of the depth of the western Mediterranean before, during and after the Late Miocene salinity crisis. Sedimentology 23, 791-813.

Ryan, W.B.F., 2011. Geodynamic responses to a two-step model of the messinian salinity crisis. Bull Soc. Géol. France 182, 73-78.

Séranne, M., 1999. The Gulf of Lion continental margin (NW MEditerranean) revisited by IBS: an overview, in: Durand, B., Jolivet, L., Horvath, F., Seranne, M. (Eds.), The Mediterranean Basins: Tertiary Extension within the Alpine Orgogen. Special publication, Geological Society of London, pp. 15-36.

Sierro, F.J. Nils Andersen, Maria A. Bassetti, Serge Berné, Miquel Canals, Jason H. Curtis, Bernard Dennielou, Jose Abel Flores, Jaime Frigola, Beatriz Gonzalez-Mora, Joan O. Grimalt, David A. Hodell, Gwenael Jouet, Marta Pérez-Folgado, Ralph Schneider, 2009. QSR, Vol. 28, Issues 25-26, p. 2867-2881

Shackleton, N.J., Opdyke, N.D., 1977. Oxygen isotopes and palaeomagnetic evidence for early Northern Hemisphere glaciation. Nature 270, 216-219.

Steckler, M.S., Watts, A.B., 1980. The Gulf of Lion: subsidence of a young continental margin. Nature 287, 425-429.

Vail, P.R., Audemard, F., Bowman, S.A., Eisner, P.N., Perez-Cruz, C., 1991. The Stratigraphic Signatures of Tectonics, Eustacy and Sedimentology-an Overview, in: al., Einsele G. Ricken, W., Seilacher, A. (Eds.), Cycles and Events in Stratigraphy. Springer-Verlag, Berlin Heidelberg, pp. 617-659.

Vail, P.R., Colin, J.P., Du Chene, R.J., Kuchly, J., Mediavilla, F., Trifilieff, V., 1987. La stratigraphie séquentielle et son application aux corrélations chronostratigraphiques dans le Jurassique du Bassin de Paris. Bull. Soc. Géol. France 8, 1301-1321.

Van Couvering, J.A., Castradori, D., Cita, M.B., Hilgen, F.J., Rio, D., 2000 The base of the Zanclean Stage and of the Pliocene Series. Episodes 23, 179-187.

Van Hinte, J.E., 1978. Geohistory analysis: application of micropaleontology in exploration geology. Bull. AAPG 62, 201-222.

Viallard, P., Gorini, C., 1994. Modalités de la fracturation d'une marge passive préstructurée : le golfe du lion (méditerranée nord-occidentale). Comptes Rendus de l'Académie des Sciences de Paris 319 (série II), 567-572.

Watts, A.B., Ryan, W.B.F., 1976. Flexure of the lithosphere and continental margin basins. Tectonophysics 36, 25-44. 


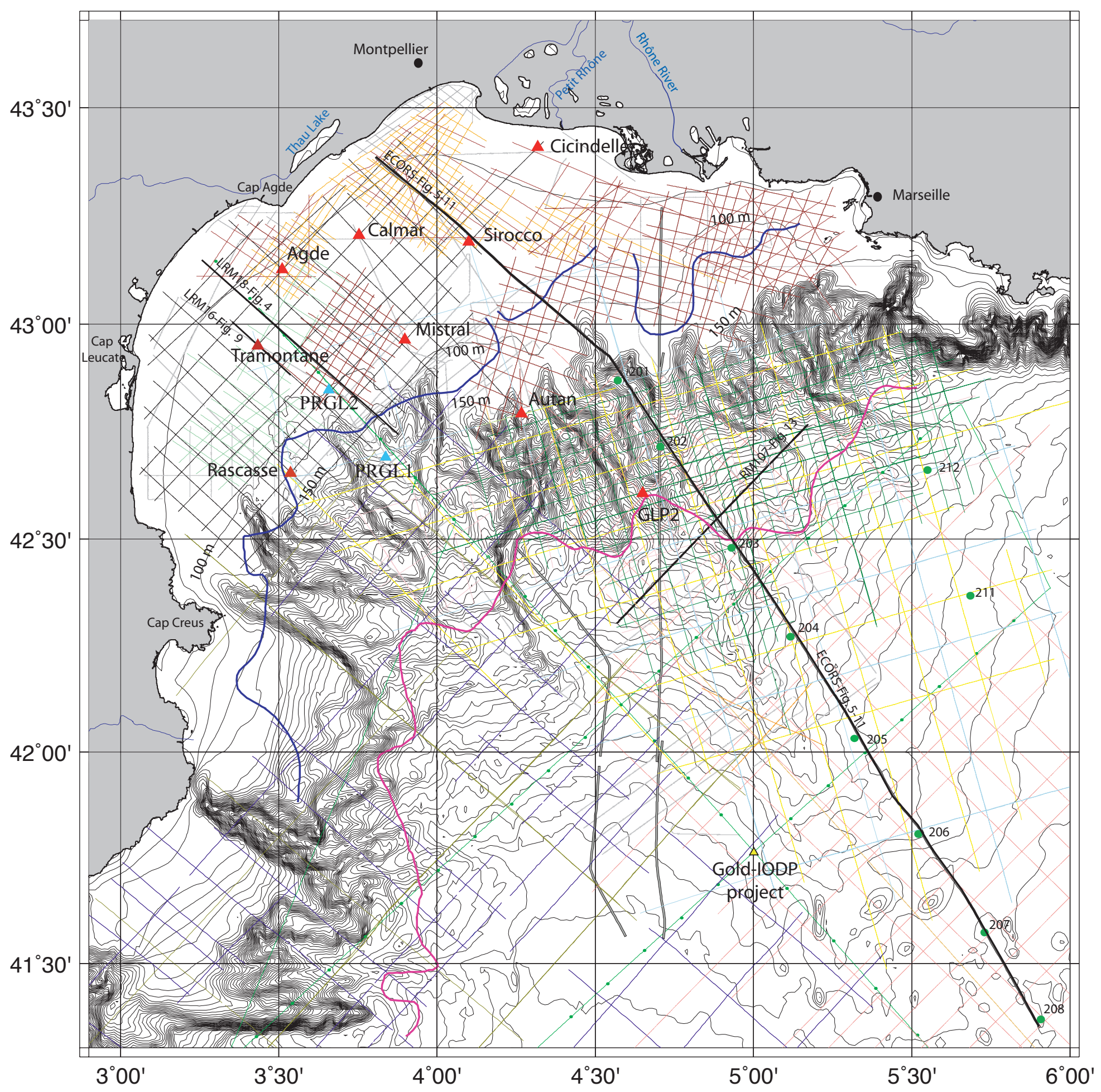

Rabineau et al., EPSL, 2014

Figure 01 
A)

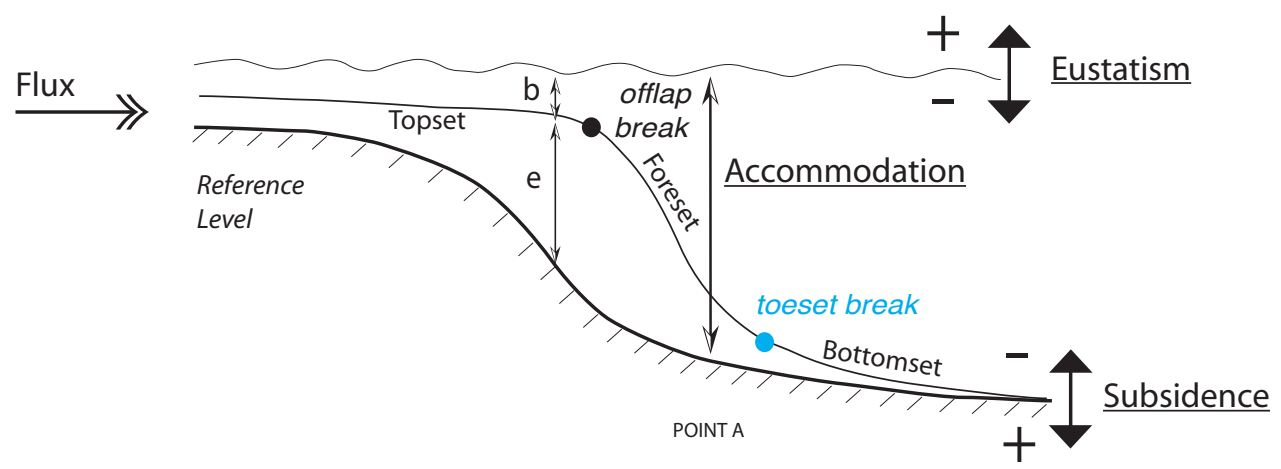

B)
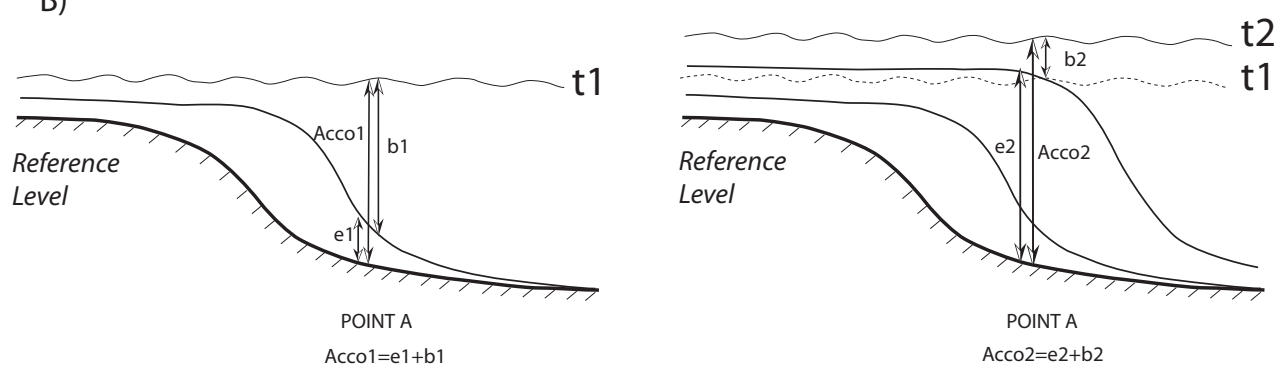

$\Delta \mathrm{Acco}(\mathrm{t} 2-\mathrm{t} 1)=\mathrm{Acco}(\mathrm{t} 2)-\mathrm{Acco}(\mathrm{t} 1)=\Delta$ subsi $(\mathrm{t} 2-\mathrm{t} 1)+\Delta$ Eustat $(\mathrm{t} 2-\mathrm{t} 1)=(\mathrm{e} 2+\mathrm{b} 2)-(\mathrm{e} 1+\mathrm{b} 1)$

$\alpha=\beta-\gamma$

C)

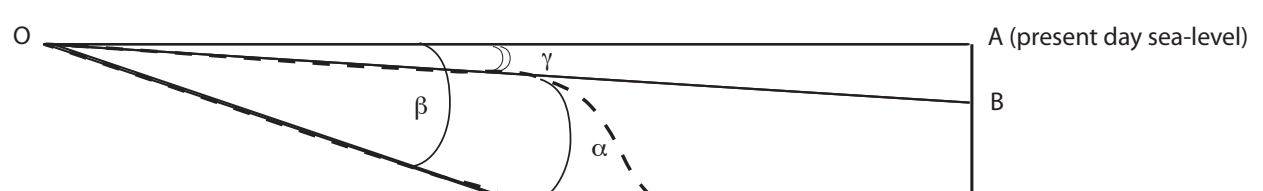

$\tan \alpha=\tan (\beta-\gamma)=(\tan \beta-\tan \gamma) /(1+\tan \beta \tan \gamma)$

$\tan \alpha=\frac{(\mathrm{AD} / \mathrm{OA})-(\mathrm{AB} / \mathrm{OA})}{(1+(\mathrm{AD} / \mathrm{OA})(\mathrm{AB} / \mathrm{OA}))}$

$\alpha=\arctan \left(\left((\mathrm{AD}-\mathrm{AB}) /(\mathrm{OA}) /\left(1+(\mathrm{AD} * \mathrm{AB}) / \mathrm{OA}^{2}\right)\right)\right.$

Rabineau et al., 2014, EPSL

Figure 02 
$\mathrm{Km}$ from Coast

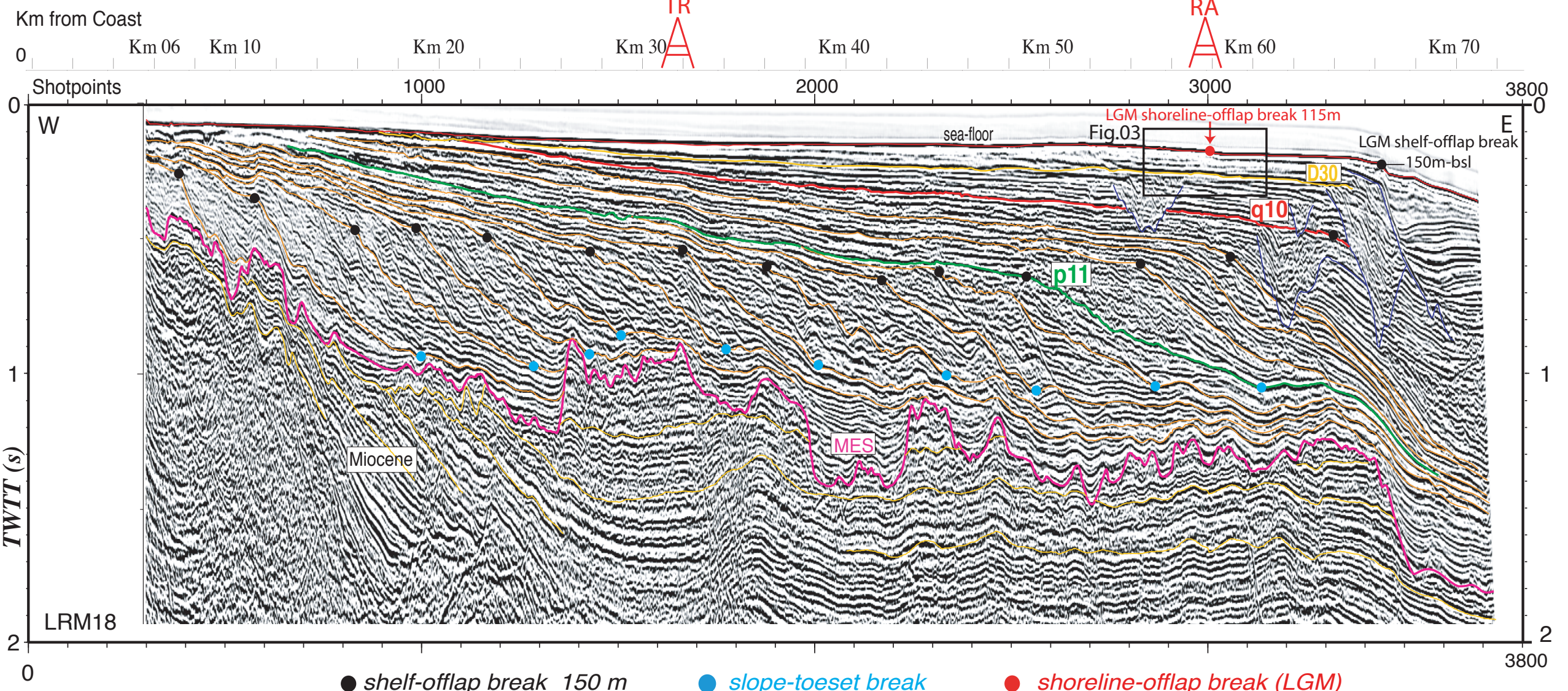

Rabineau et al., EPSL, 2014

Figure 03 


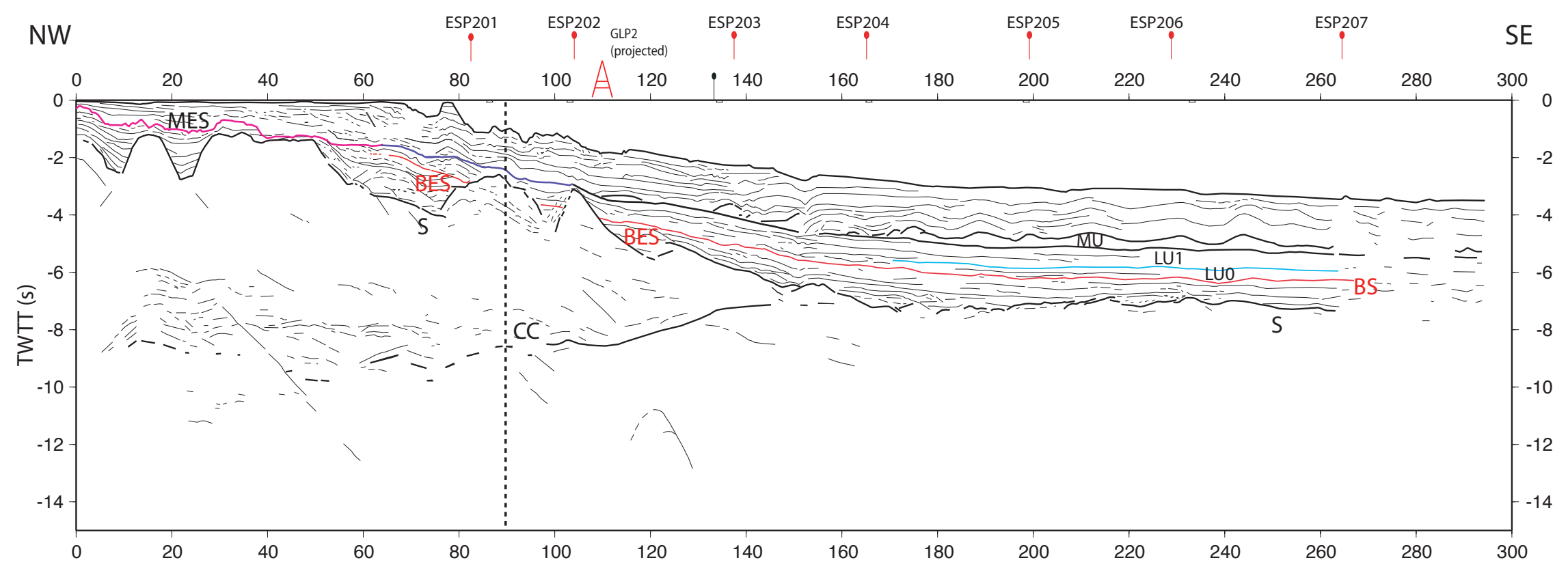

Rabineau et al. EPSL, 2014

Figure 04 

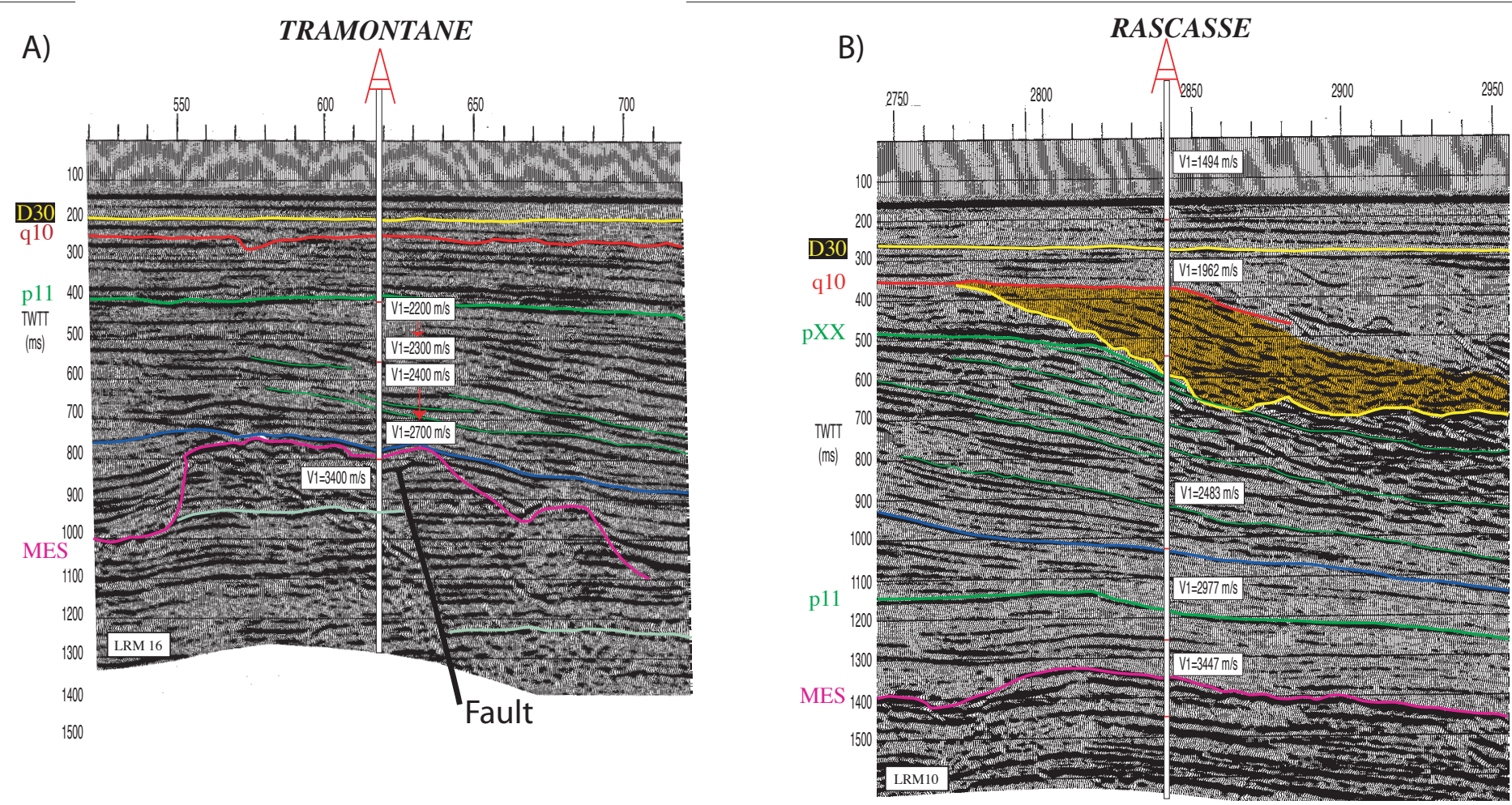

TRAMONTANE
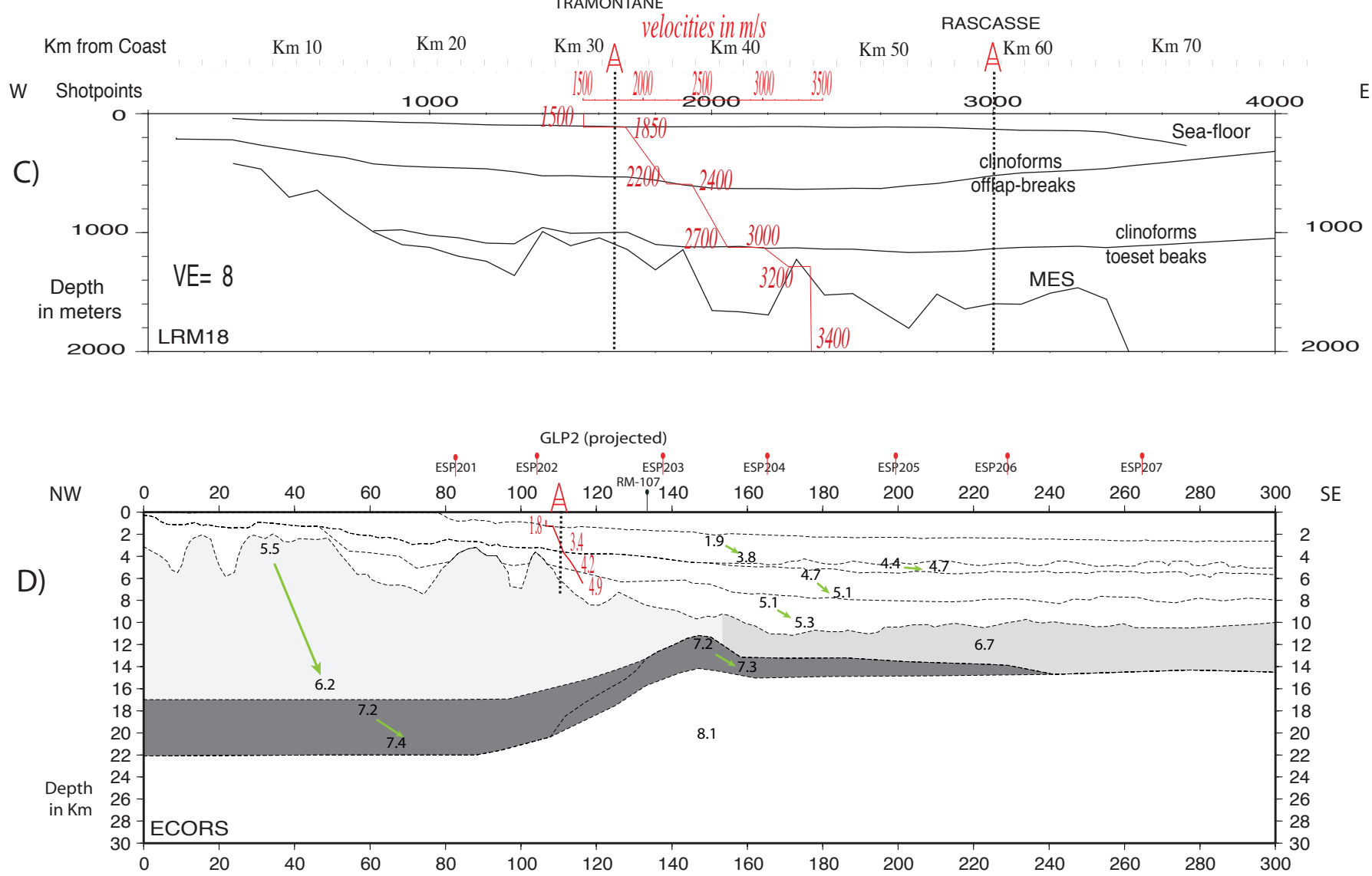

Rabineau et al., EPSL, 2014

FIGURE 5 


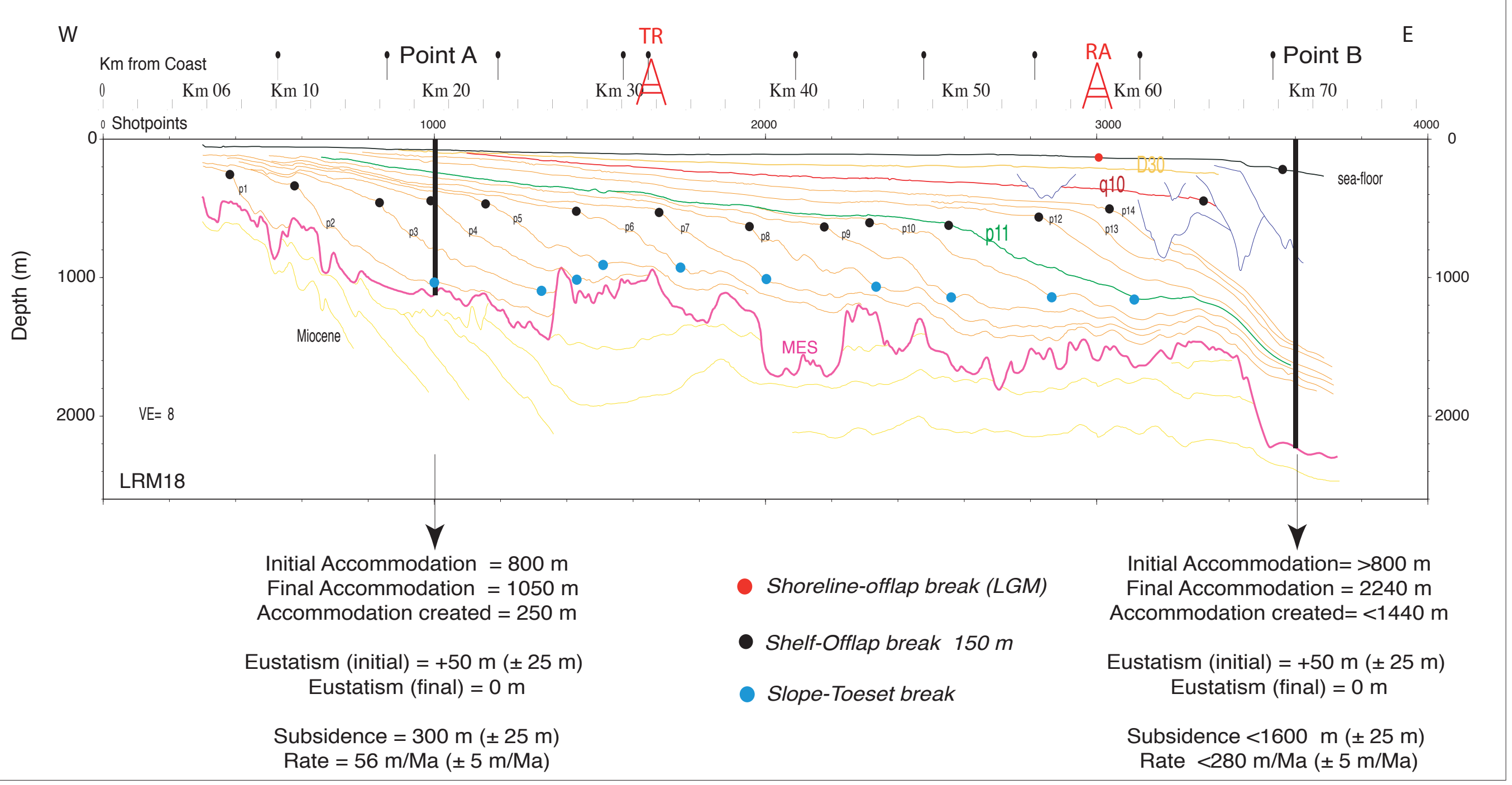




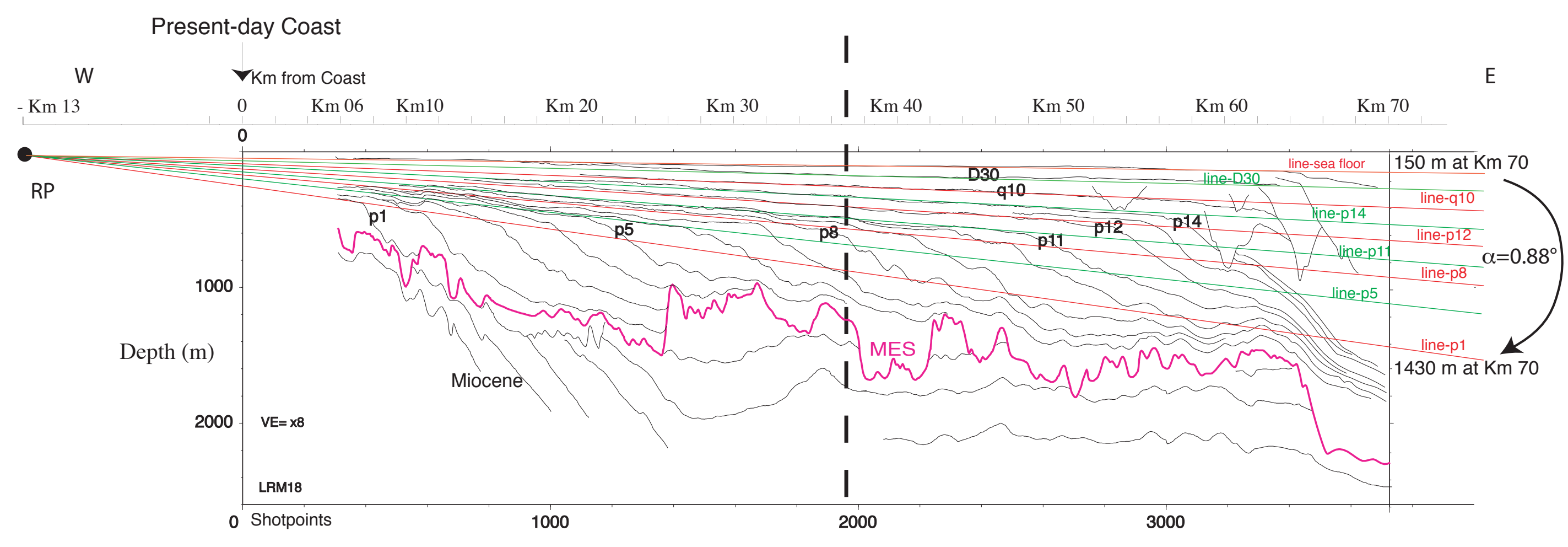

Rabineau et al., EPSL, 2014

Figure 7 
A)

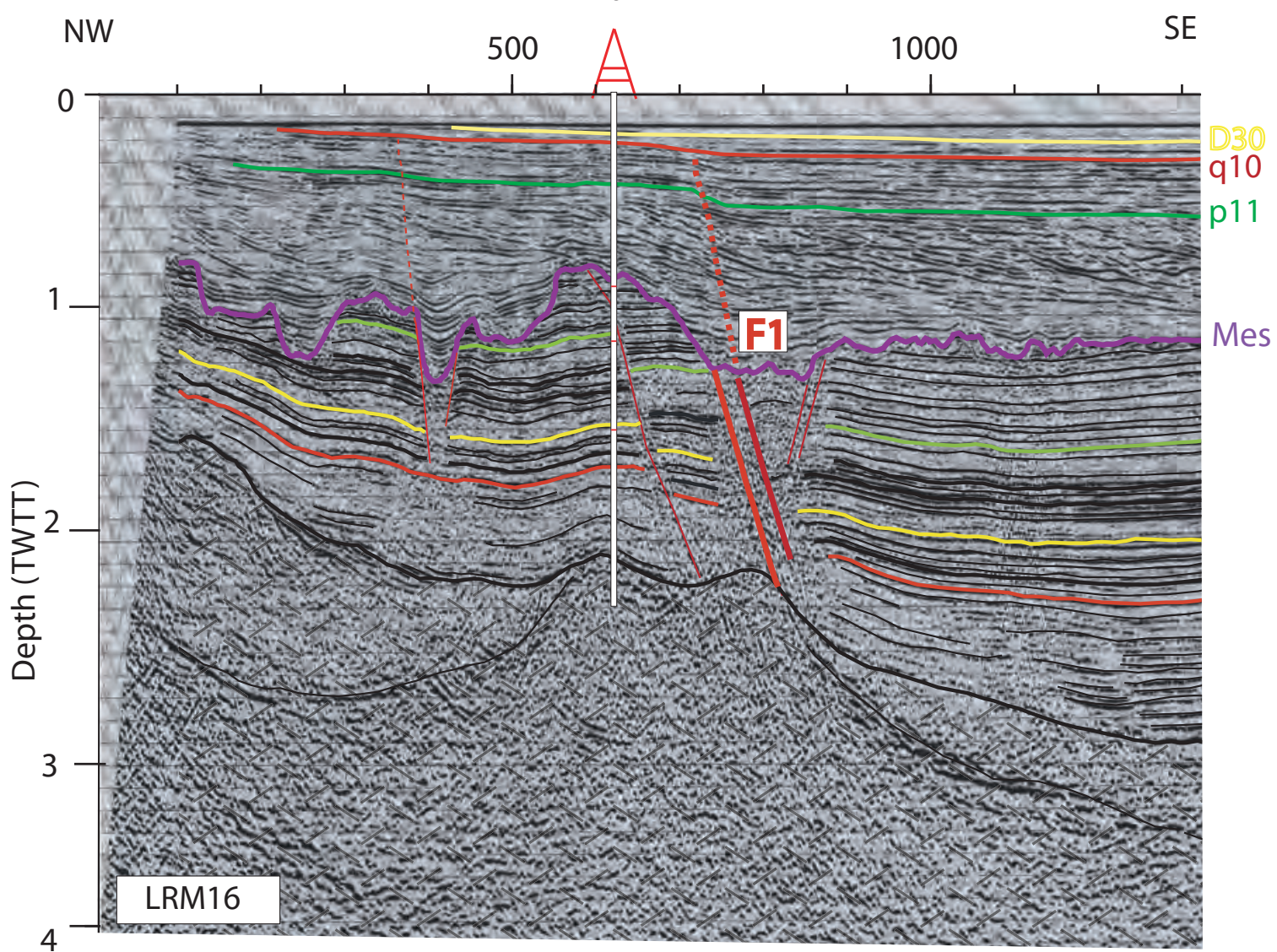

B)

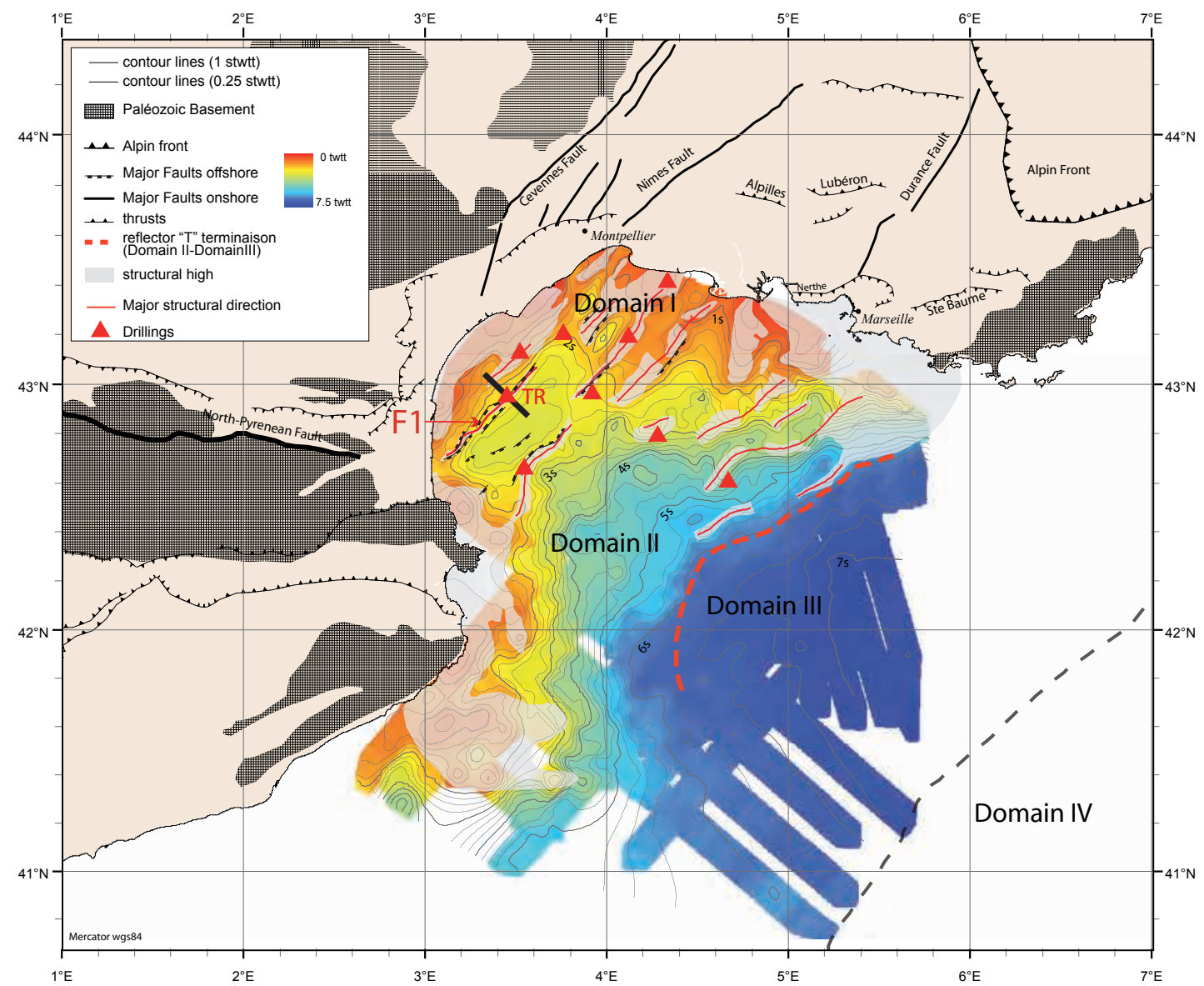

Rabineau et al., 2014, EPSL

Figure 8 

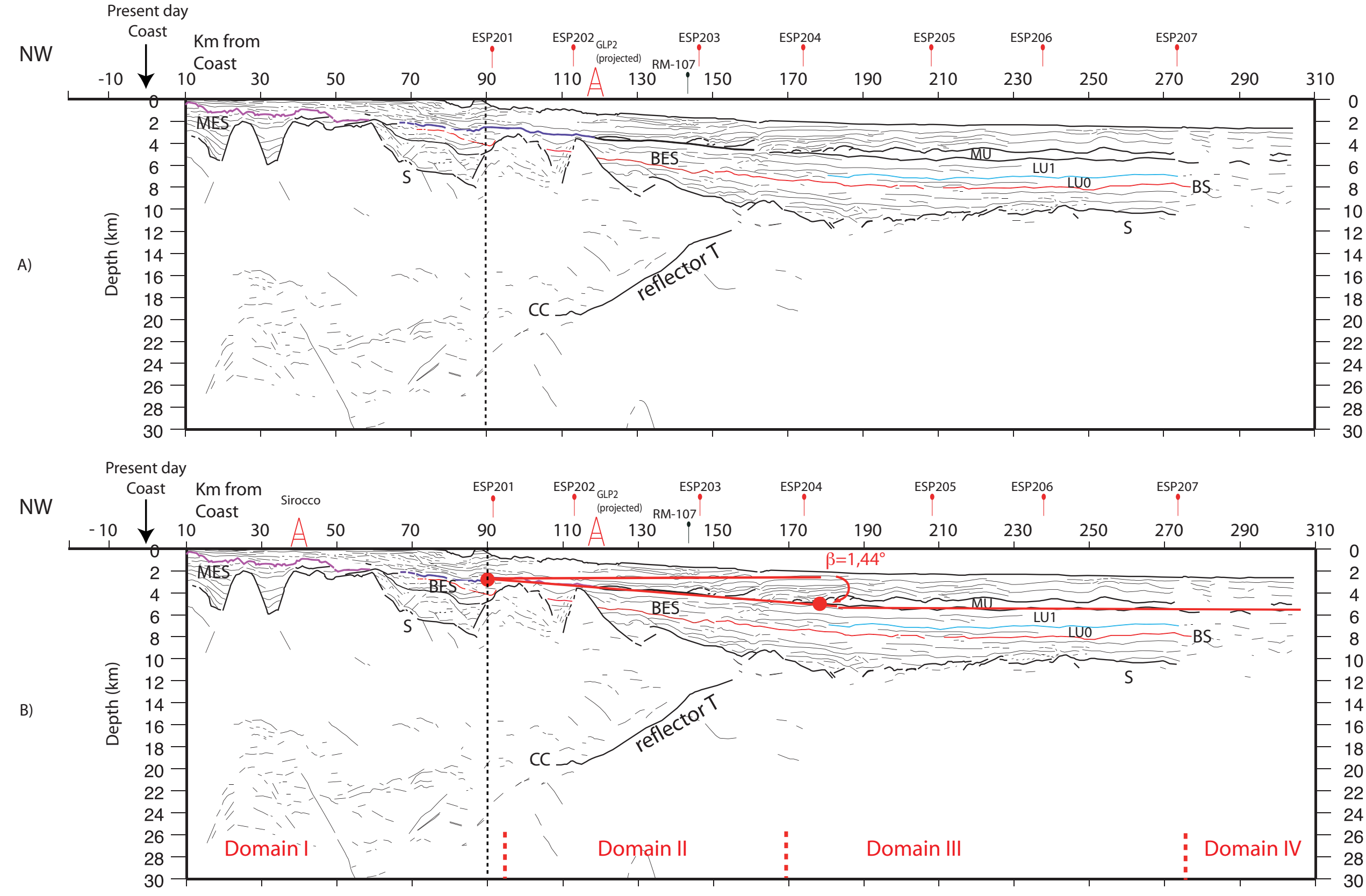
Petit Rhône Canyon outlet and Deep sea Fan

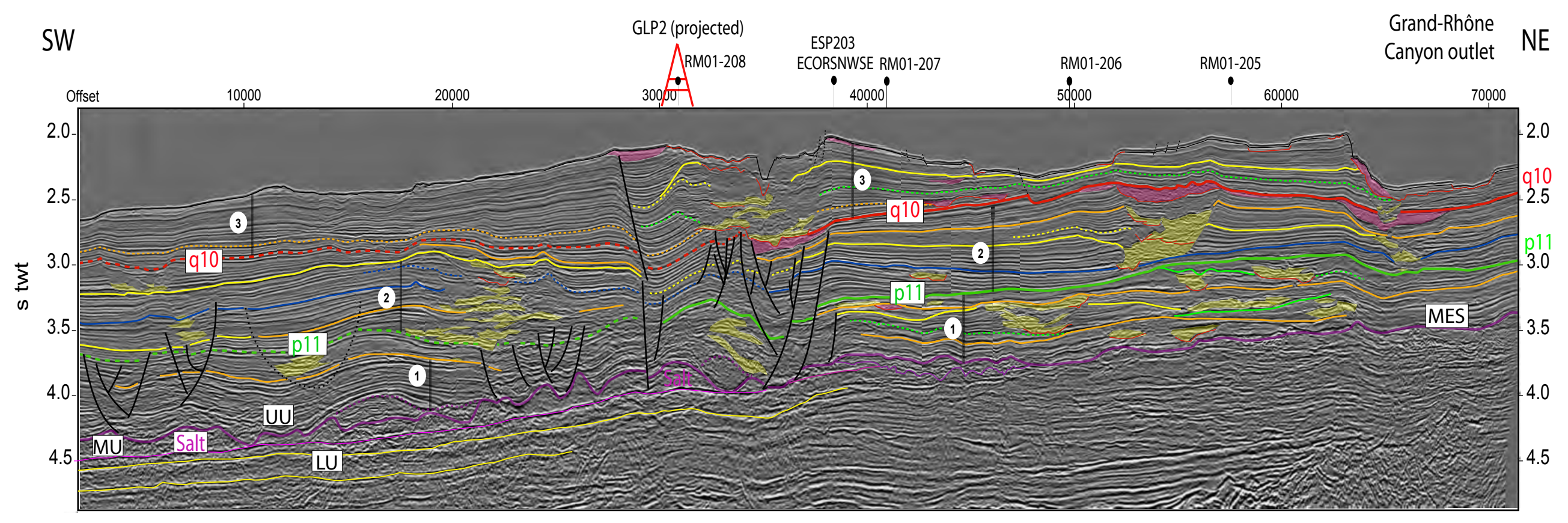




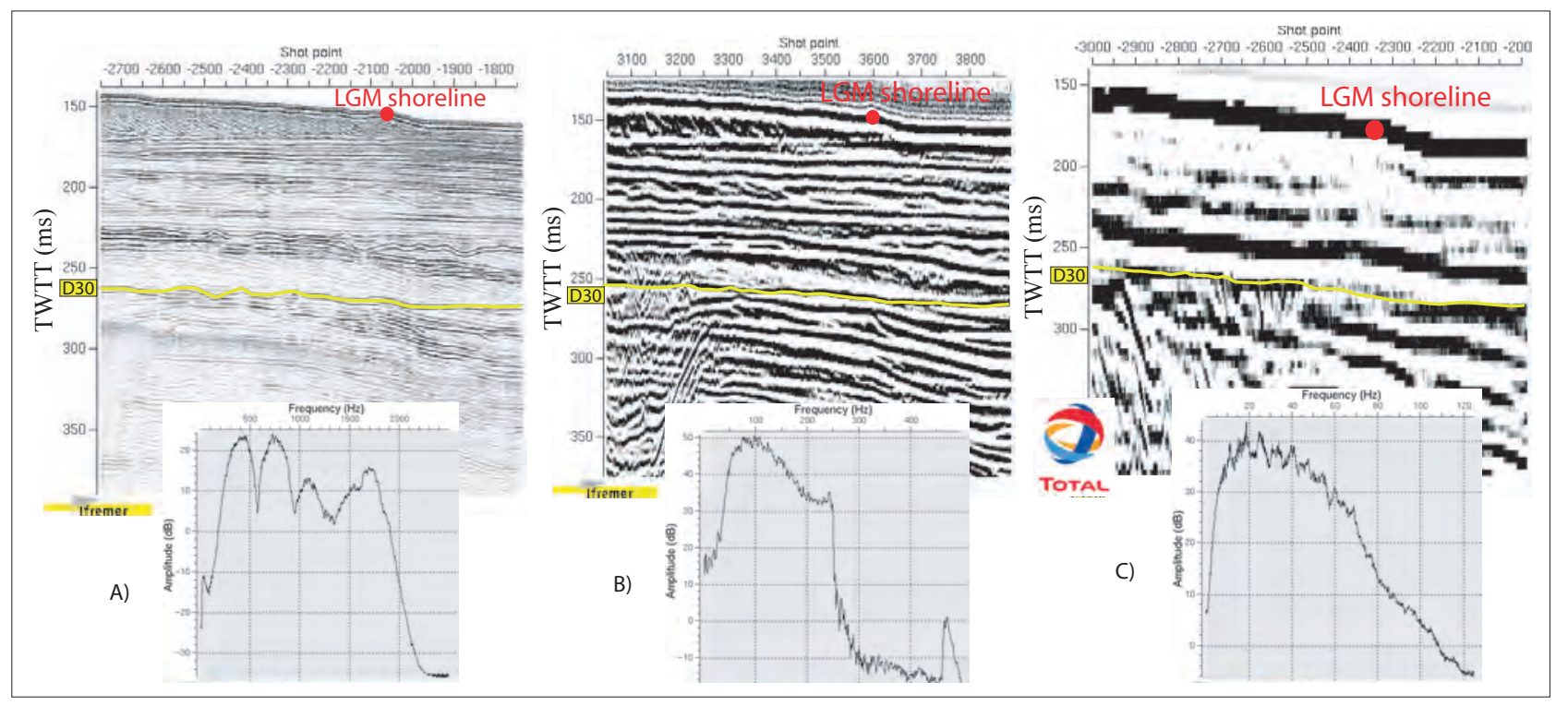

Rabineau et al., 2014 EPSL

Figure S1 


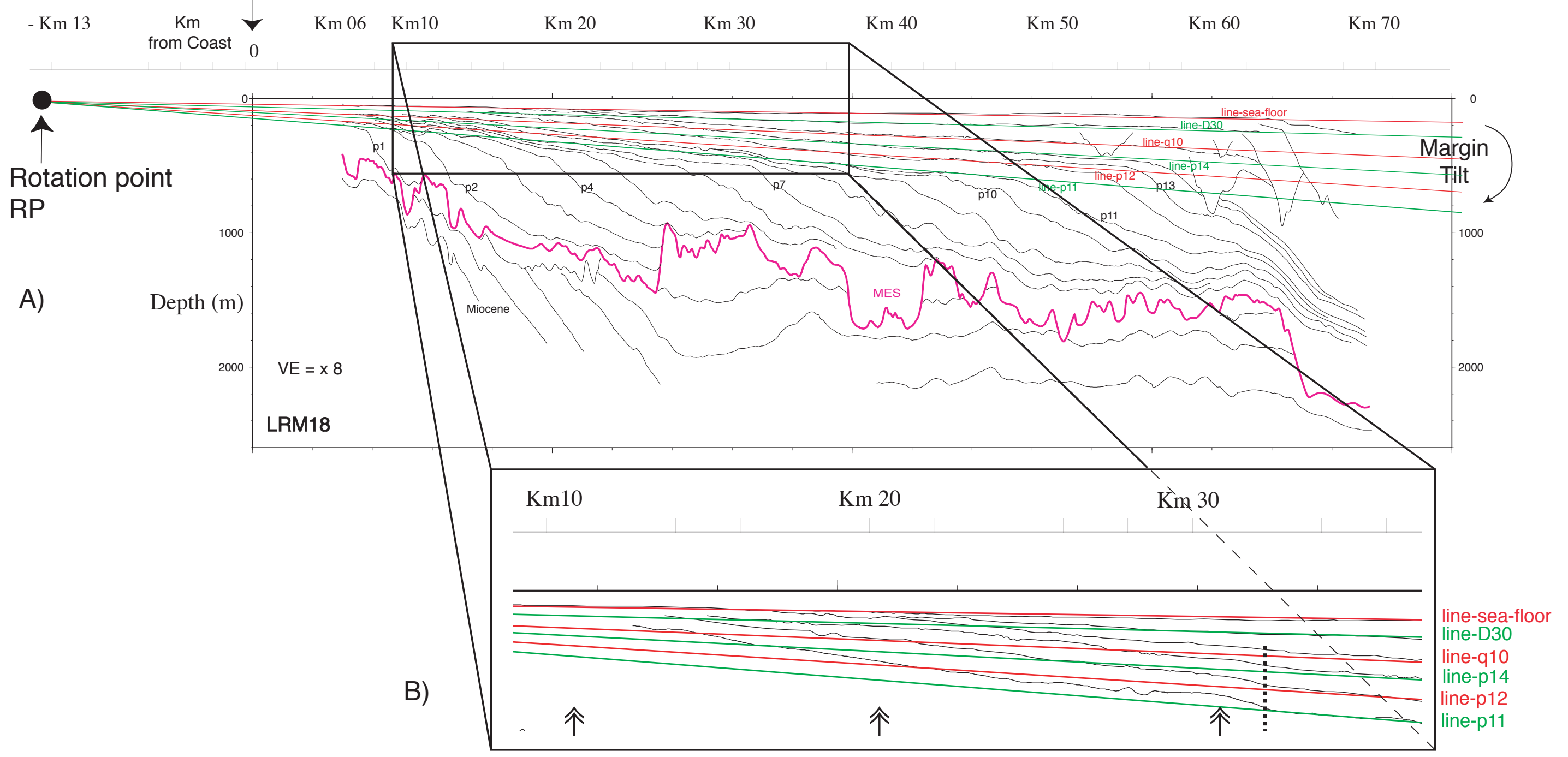

